\title{
Ethnomedicinal Investigation of Medicinal Plants of Chakrata Region (Uttarakhand) Used in the Traditional Medicine for Diabetes by Jaunsari Tribe
}

\author{
Ankit Kumar ${ }^{1} \cdot$ Sonali Aswal' ${ }^{1}$ Ashutosh Chauhan ${ }^{2} \cdot$ Ruchi Badoni Semwal $^{3} \cdot$ Abhimanyu Kumar $^{4}$. \\ Deepak Kumar Semwal ${ }^{5}$ (D)
}

Received: 20 January 2019 / Accepted: 26 March 2019 / Published online: 9 April 2019

(c) The Author(s) 2019

\begin{abstract}
The Himalayan region is the treasure house of natural wealth, particularly of medicinal and aromatic plants. These plants are used by the Indian traditional healers for the past many centuries to treat various ailments such as skin disorders, asthma, diabetes, snake bite, fever, pain, eye diseases, diarrhoea, indigestion, jaundice, burn, wound, liver disorder, CNS disorders and urinary tract infection. The indigenous traditional knowledge of medicinal plants and therapies of various local communities has been lost due to changes in traditional culture and the introduction of modern technologies. Therefore, it is essential to explore the traditional knowledge of the indigenous medicinal plants mainly in such areas where there is a severe threat to natural vegetation owing to human inhabitation. The present study aimed to explore the medicinal plants of Chakrata region (Jaunsar-Bawar Hills), Uttarakhand, India used in the folk medicine for the management of diabetes by Jaunsari Tribe. In a comprehensive field survey, the information about the medicinal plants have been mainly collected from the traditional healers and other elderly people belong to the tribal community. All the information about the medicinal plants of the study area was documented in a field book. Various tools have been used to collect the samples for identification purpose and the authentication of the plants was done with the help of taxonomists. The literature on these plants was also searched from online (PubMed and Scopus) as well as from some textbooks and Ayurvedic classical texts. The present survey-based work described a total of 54 plants belonging to 47 genera and 30 families used in the traditional medicine for the management of diabetes in Chakrata region. The information gathered from the local community revealed that the plants are effective in diabetes and one can use most of them without consulting a practitioner or traditional healer. The literature revealed that most of the surveyed plants are already used in the preparation of various antidiabetic formulations such as Chandraprabha vati, Nishamalaki chunra, Amritamehari churna and Nisakathakadi kashayam along with various patent drugs which are frequently prescribed by the Ayurvedic practitioners in India. The present study explored the traditional as well as scientific knowledge on the antidiabetic plants used by the tribal community. The documented information on these plants can be further used by the scientific community to develop new drugs/formulations with the help of modern techniques.
\end{abstract}

Keywords Ayurveda $\cdot$ Diabetes $\cdot$ Herbal formulations $\cdot$ Traditional healers $\cdot$ Folk medicine

Deepak Kumar Semwal

dr_dks.1983@yahoo.co.in

1 Research and Development Centre, Faculty of Biomedical Sciences, Uttarakhand Ayurved University, Harrawala, Dehradun 248001, India

2 Department of Biotechnology, Faculty of Biomedical Sciences, Uttarakhand Ayurved University, Harrawala, Dehradun 248001, India
3 Department of Chemistry, Pt. Lalit Mohan Sharma Government Postgraduate College, Rishikesh, Uttarakhand 249201, India

4 Uttarakhand Ayurved University, Harrawala, Dehradun 248001, India

5 Department of Phytochemistry, Faculty of Biomedical Sciences, Uttarakhand Ayurved University, Harrawala, Dehradun 248001, India 


\section{Abbreviations}

STZ Streptozotocin

ALX Alloxan

GTT Glucose tolerance test

\section{Introduction}

Human has been directly or indirectly depending on the plants since time immemorial to fulfil his daily needs like food, oxygen, medicine and timber. Medicine is one of the essential necessities of a human, and the plants are the primary source of it. The plants have therapeutical importance to treat various kind of human and livestock ailments due to the presence of a variety of bioactive secondary metabolite. In different traditional medicinal systems like Indian and Chinese, these plants are used as a whole or their derived products in the form of different formulations. This ancient system of healthcare is also relevant and effective in the present time when technological progress has been drastically altered the individual's lifestyle.

India is one of the mega-diversity countries recognised by the World Conservation Monitoring Centre in 2000. Its total geographical area is nearly 329 million hectares comprised of forests, grasslands, wetlands, coastal, marine and desert. India has an enormous ecological diversity ranging from sea level to the highest mountains. It represents $2.4 \%$ of world's total geographical area with about 47,513 plants species out of 465,668 including microorganisms like virus, bacteria and fungi worldwide. The total numbers of species of angiosperms, bryophytes, pteridophytes and gymnosperms found worldwide are 268600, 16236, 12000 and 1021, respectively [1], whereas, in India, these are 18043, 2523, 1267 and 74, respectively. Among them, 4036, 629, 47 and 8, respectively are reported to endemic to India [2]. In India, about 280 medicinal plants belonging to 79 families are used by pharmaceutical industries to prepare different formulation used in Ayurvedic, Homeopathy, Unani, Siddha and even in Allopathic medicine, of which about 175 medicinal plants are found in the Himalayan region of India [3].

Diabetes mellitus is a metabolic disorder characterised by a high blood glucose level mainly due to the problem of inadequate insulin secretion by the pancreatic $\beta$-cells. A continuous high level of glucose in the blood can lead to serious complications such as neuropathy, retinopathy and nephropathy. In addition, one can become prone to heart attack and stroke if the glucose level is not maintained regularly. The patients of this deadly disease have been increased sharply in the past few years and still, the graph is rising rapidly. In 2013, the number of diabetic patients was about 422 million whereas this number was about 108 million in 1980. The cases of diabetes are recorded more in middle and low-income countries than in high-income countries.
In 2015, about 1.6 million deaths were recorded due to diabetes mellitus. The majority of cases belong to type 2 diabetes mellitus, and these are about $80-90 \%$ of total diabetic cases. According to the World Health Organization [4], diabetes imputes the largest burden on the global economy and healthcare system. South-East Asia region which includes India, Bangladesh, Maldives, Nepal, Mauritius and Sri Lanka has one fifth ( 84 million) of the total number of people with diabetes in the world, and hence called as the home of diabetes.

\section{Geography and Culture of the Study Area}

Uttarakhand Himalaya is characterised as one of the microdiversity centres of the Indian subcontinent. Chakrata, also known as Jaunsar-Bawar, is a hilly region in district Dehradun situated at a height ranging from 1500 to $2150 \mathrm{~m}$. The Jaunsar region is the lower half while the snow-clad upper region is called Bawar. A tribal community, known as Jaunsari is inhabited in this region, and the native language spoken by them is Jaunsari, although Hindi is also spoken frequently. The culture of Jaunsari people is distinct from other natives of Uttarakhand and Himachal Pradesh, a neighbour hill state. The main occupation of this community is agriculture and animal husbandry. Geographically, it has rich vegetation and mostly covered by forest areas. The region is well-known for the medicinal plant diversity which includes many rare plants [5].

The villages of Chakrata come under remote areas, therefore, less developed community centres and hospitals situated in the region. The insufficient medical facilities make compulsion to the people to use home remedies for all kind of health problems. Local traditional healers or Vaidyas works as the medical practitioner using native herbs based on traditional knowledge. Majority of the population believe in traditional medicine rather than modern treatment until unless a major problem occurs. The geographical location of the study area is shown in Fig. 1.

\section{Materials and Methods}

\subsection{Data Collection}

The literature based on the area, vegetation, population, social customs and culture of the study area has been studied before starting the field visits to the Chakrata region. A comprehensive field survey was conducted in the entire Chakrata region, including Tiuni, Deovan, Sahiya and Lokbar sites during February to March 2018. A total of four visits have been organised to get the maximum advantage of the tribal population to collect information about their plant 


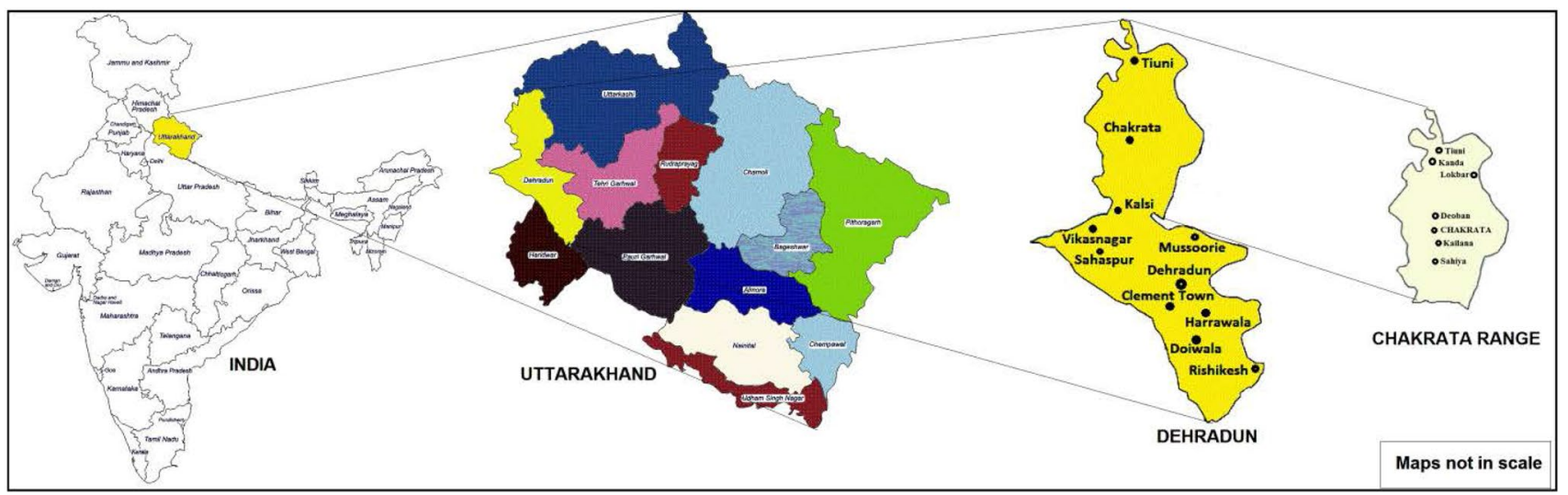

Fig. 1 Geographical location of Chakrata region

resources for various purposes, mainly for the treatment of diabetes. The information was collected from the local tribal community, elder people, local traditional healers (Vaidyas) and some employees from the State Forest Department posted in this area. In addition to the general conversations with the informants, the questionnaires were also used to obtain information on the medicinal plants with their local names, parts used, mode of preparation and administration. The plants/parts used for the purpose of diabetes were also collected during the field visits for their taxonomical authentication. The collected plants/parts were kept in the deep fridge $\left(-20{ }^{\circ} \mathrm{C}\right)$ until their further use. After the identification, the plants/parts were pressed, dried and mounted on the herbarium sheets and preserved in the phytochemistry laboratory for future records.

\subsection{Data Analysis}

During the survey, a total of 54 antidiabetic plants belonging to 47 genera and 30 families have been collected. The identification of the plants was done by Dr. M.R. Uniyal (Materia Medica Expert), Dr. A.K. Agrawal (Taxonomist, Govt PG College, Uttarkashi), Dr. Suresh Chaubey and Dr. R.C. Tiwari (Uttarakhand Ayurved University, Rishikul Campus, Haridwar). The identification also confirmed on basis of the local names of plants mentioned in the local Floras of Uttarakhand and the Himalayas. An in-depth literature search was conducted to confirm the scientific names of the antidiabetic plants. The updated botanical names of all plants were cross-checked from the Plant List, a working list of all plant species [6]. After identification, the scientific literature based on the antidiabetic potential of the medicinal plants was reviewed from the online database (PubMed and Scopus) and textbooks as well as from ancient Ayurvedic texts (Samhitas and Nighantus). Based on the literature survey, selected antidiabetic activity-based information has been included in the text for the scientific validation of traditional knowledge.

\section{Results and Discussion}

Based on the field survey, about 120 species of medicinal plants were initially identified in the Chakrata region, of which, 54 plants (belonging to 47 genera and 30 families) were recorded as antidiabetic plants used in the traditional medicine. The highest number of anti-diabetic plants were documented in the family Lamiaceae (5) followed by Zingiberaceae (4), Amaryllidaceae (3), Apocynaceae (3), Compositae (3), Menispermaceae (3) and Moraceae (3). Out of 54 plants, 31 plants were found as cultivated and 15 as wild whereas 8 species were recorded as both cultivated and wild. The details of the above plants are given in Table 1, which contains information about the methods of administration and the selected pharmacological evidence of the antidiabetic plants with well-supported by relevant references. The results showed that most of the plants/parts are used in the form of decoction to treat diabetes.

During the field survey, it has been noted that Artemisia sp., C. pareira, J. adhatoda, S. virginianum and V. negundo are commonly found in roadside areas from Sahiya to Chakrata. On the other hand, B. aristata, M. philippensis and $S$. glabra are the common plants in light forest areas. T. chebula, T. bellirica and P. emblica are found in edges of fields whereas $B$. ciliata is available at the rocky areas.

Various preclinical and clinical studies, as shown in Table 1, confirmed the role of surveyed plants in the diabetes mellitus. In addition to the crude extracts, various pure molecules have also been investigated as antidiabetic agents such as alliin, betulin, berberine, gymnemic acid and vasicine. Some mechanism-based studies also unravelled the involvement of different pathways in the antidiabetic activity of crude extracts or isolated molecules (Fig. 2). 


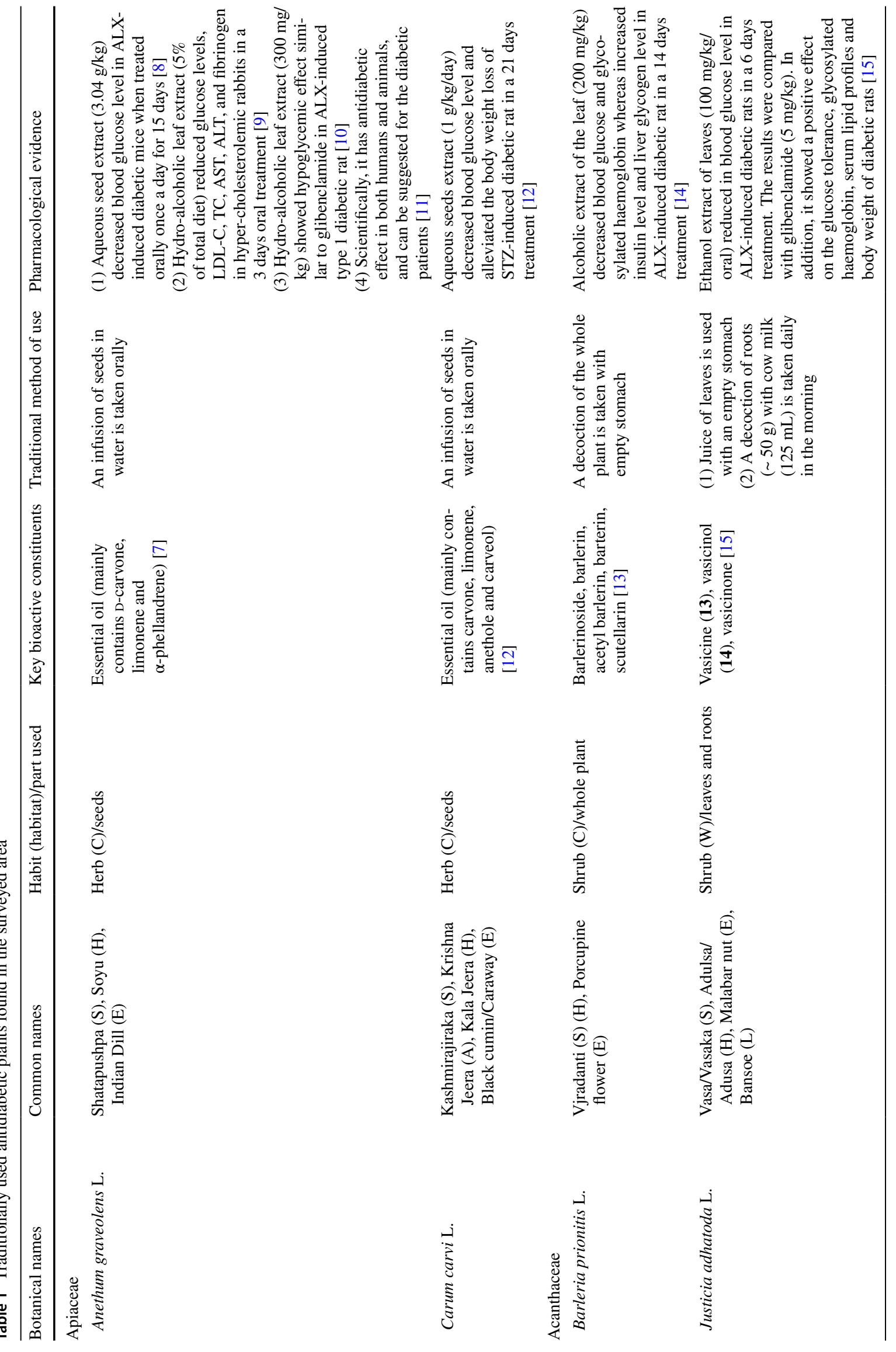




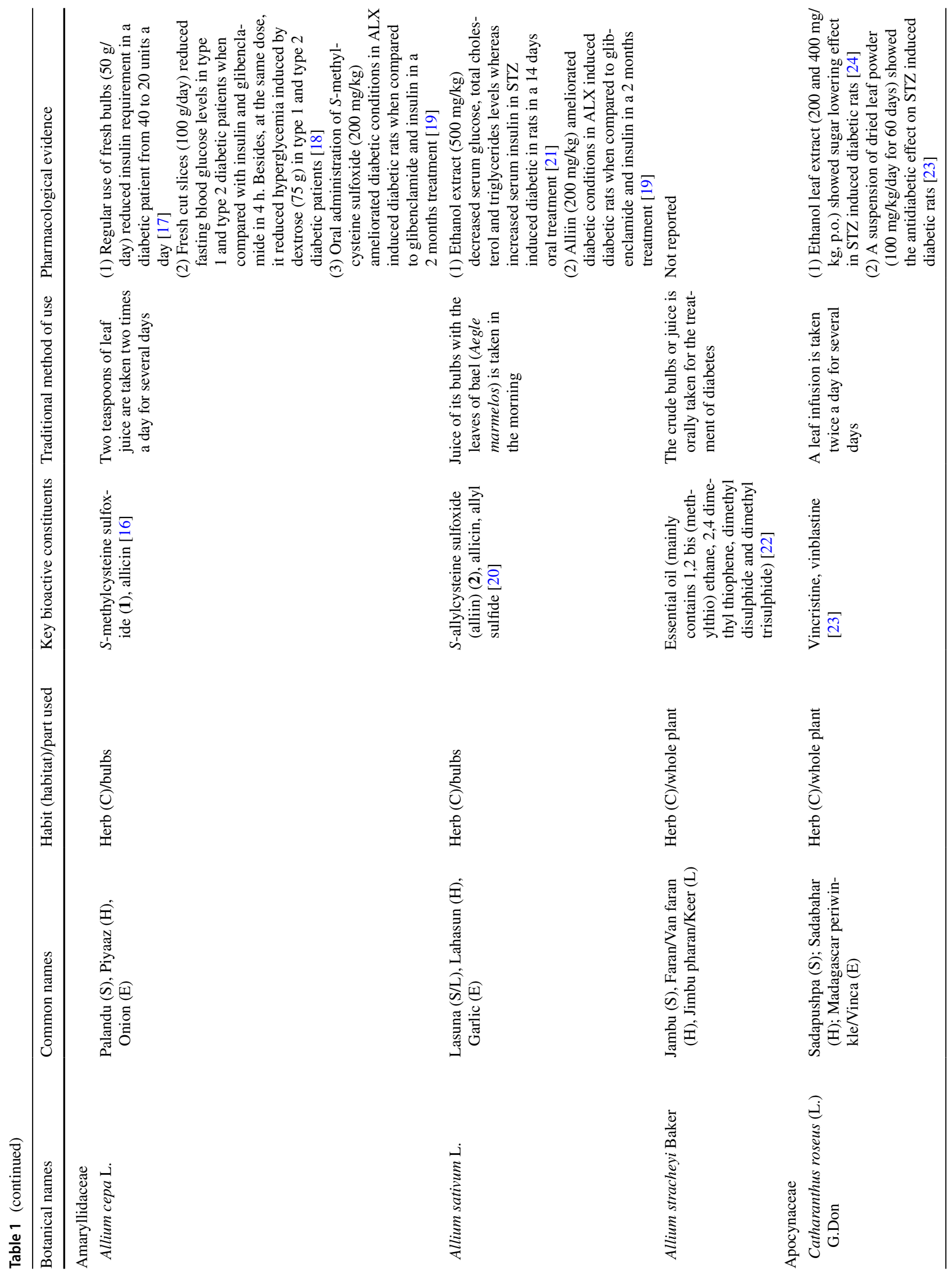




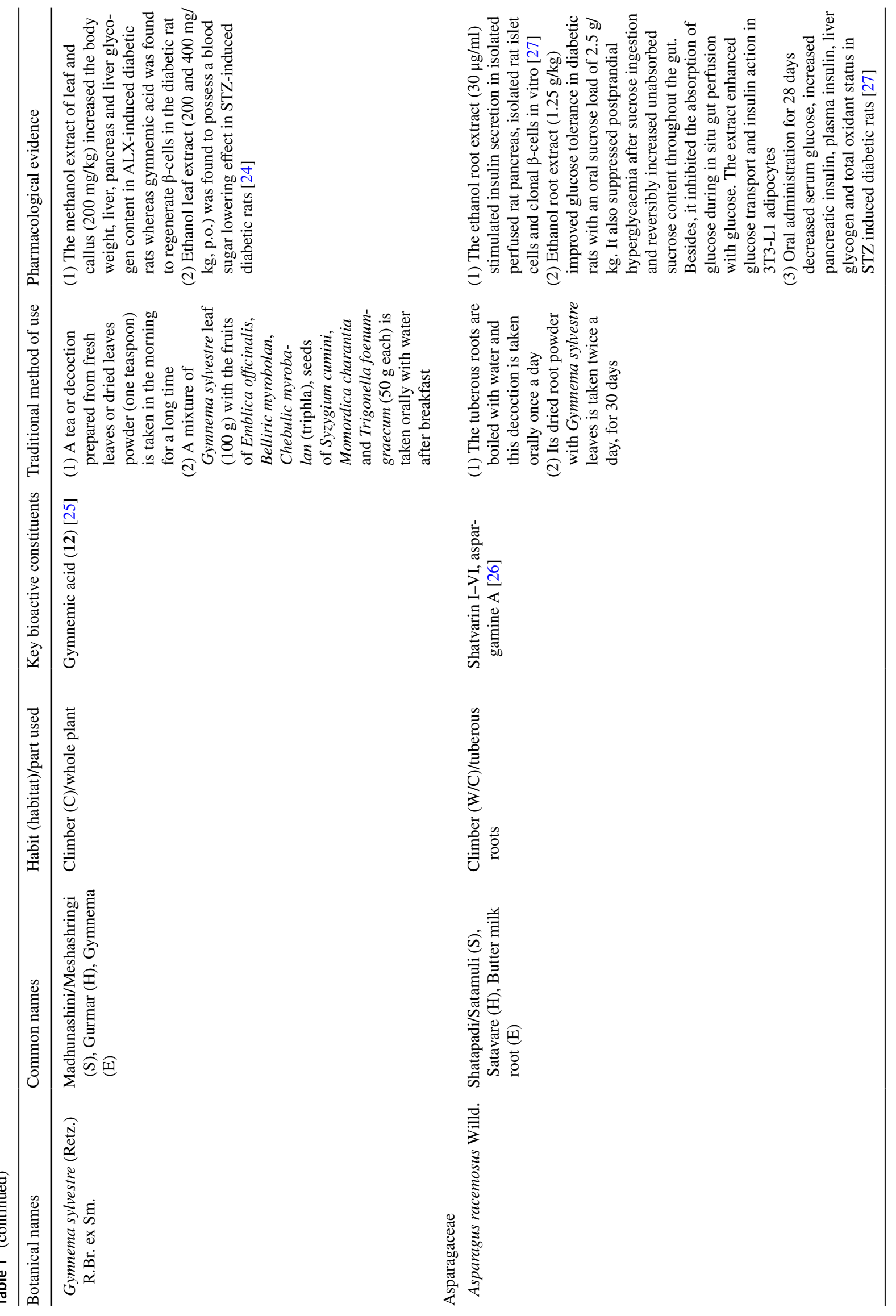




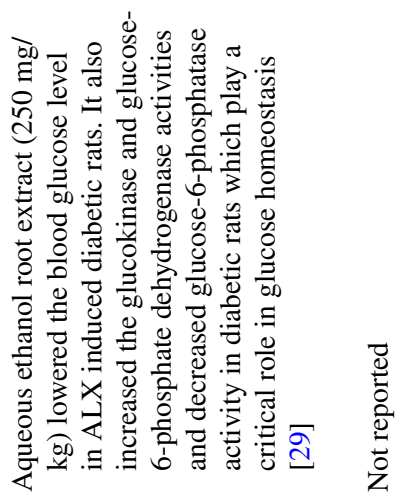

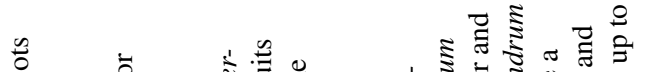

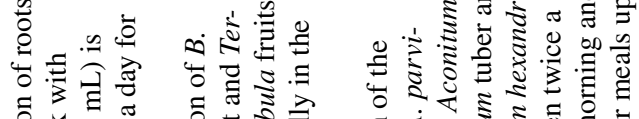

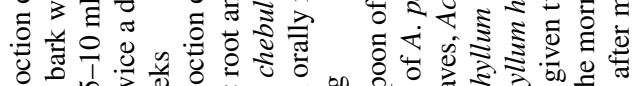

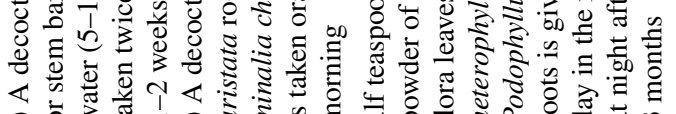

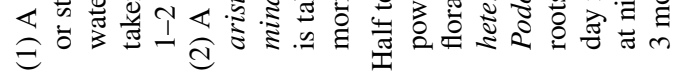

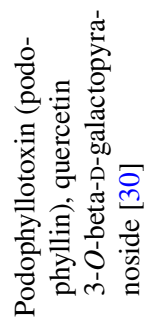

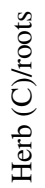

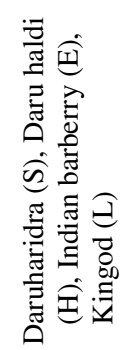

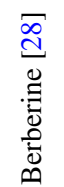

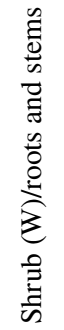

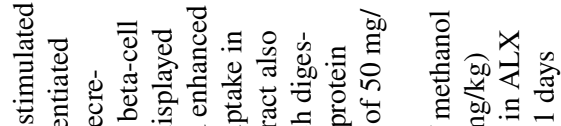

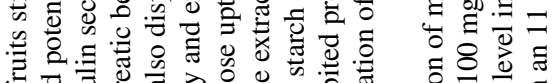

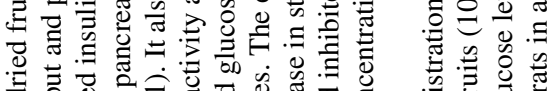

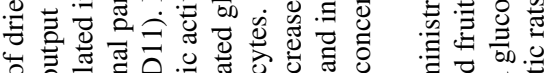

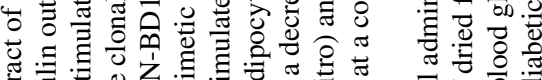

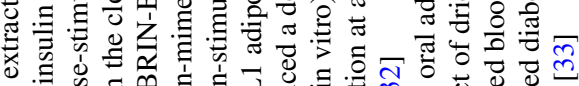

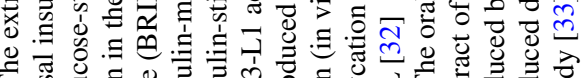

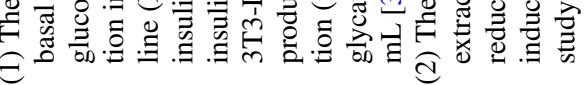

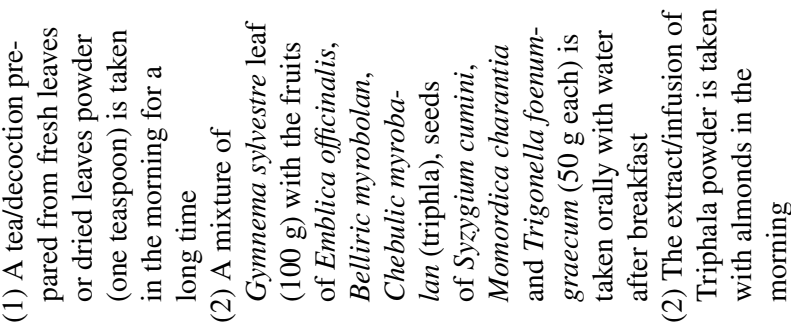

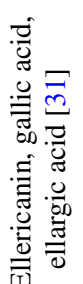

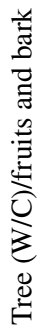

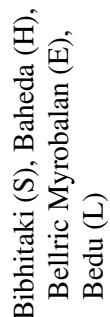




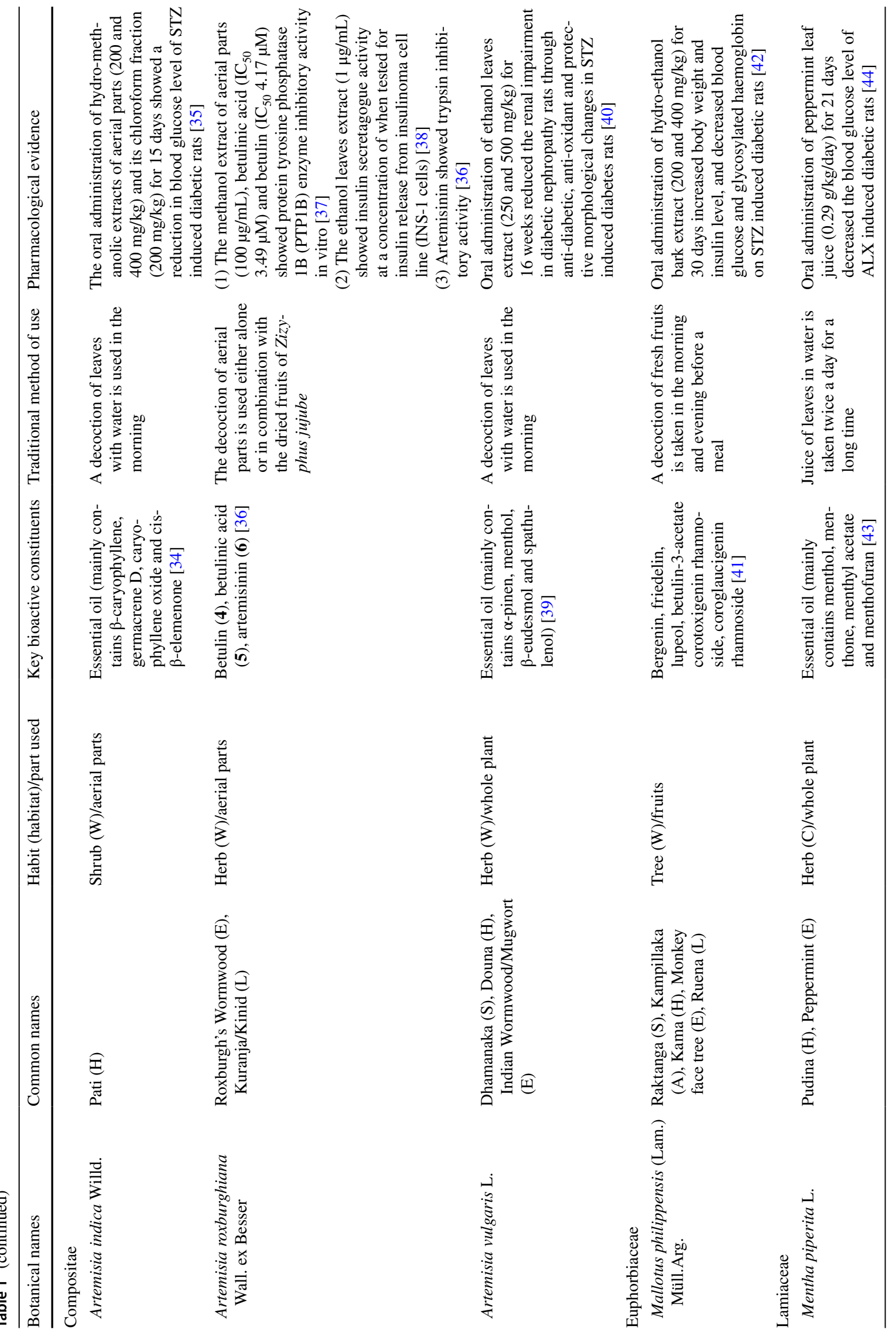




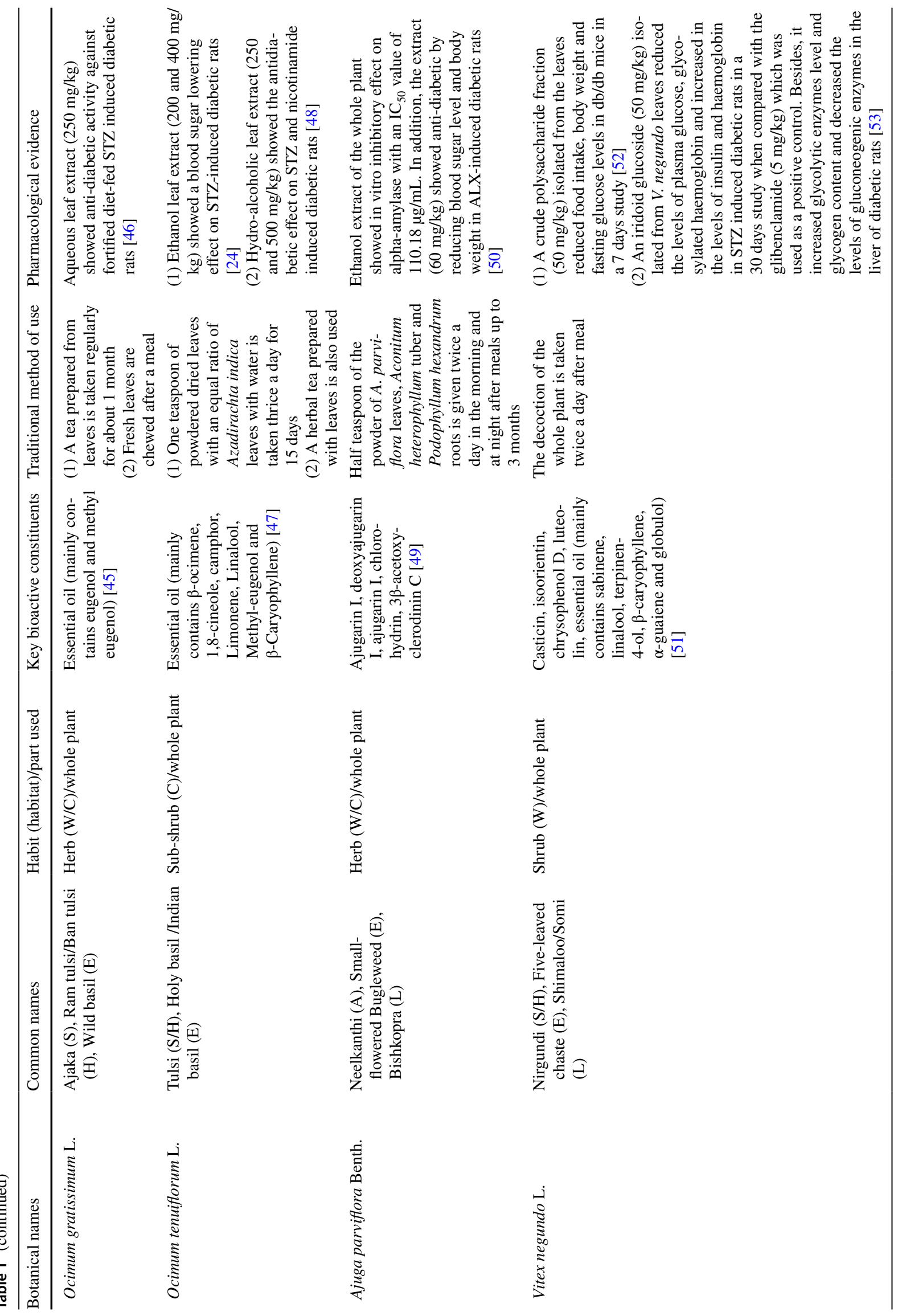




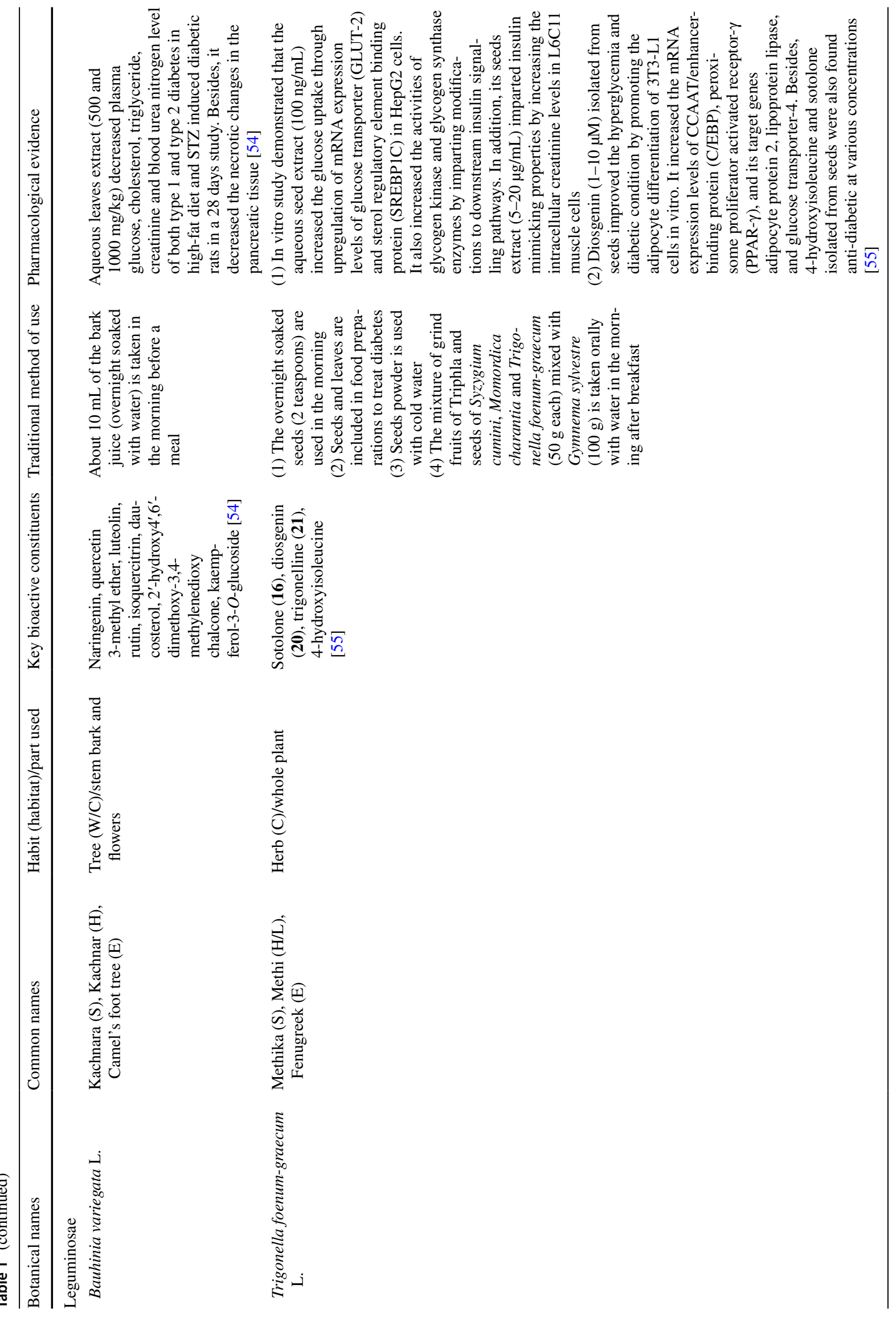




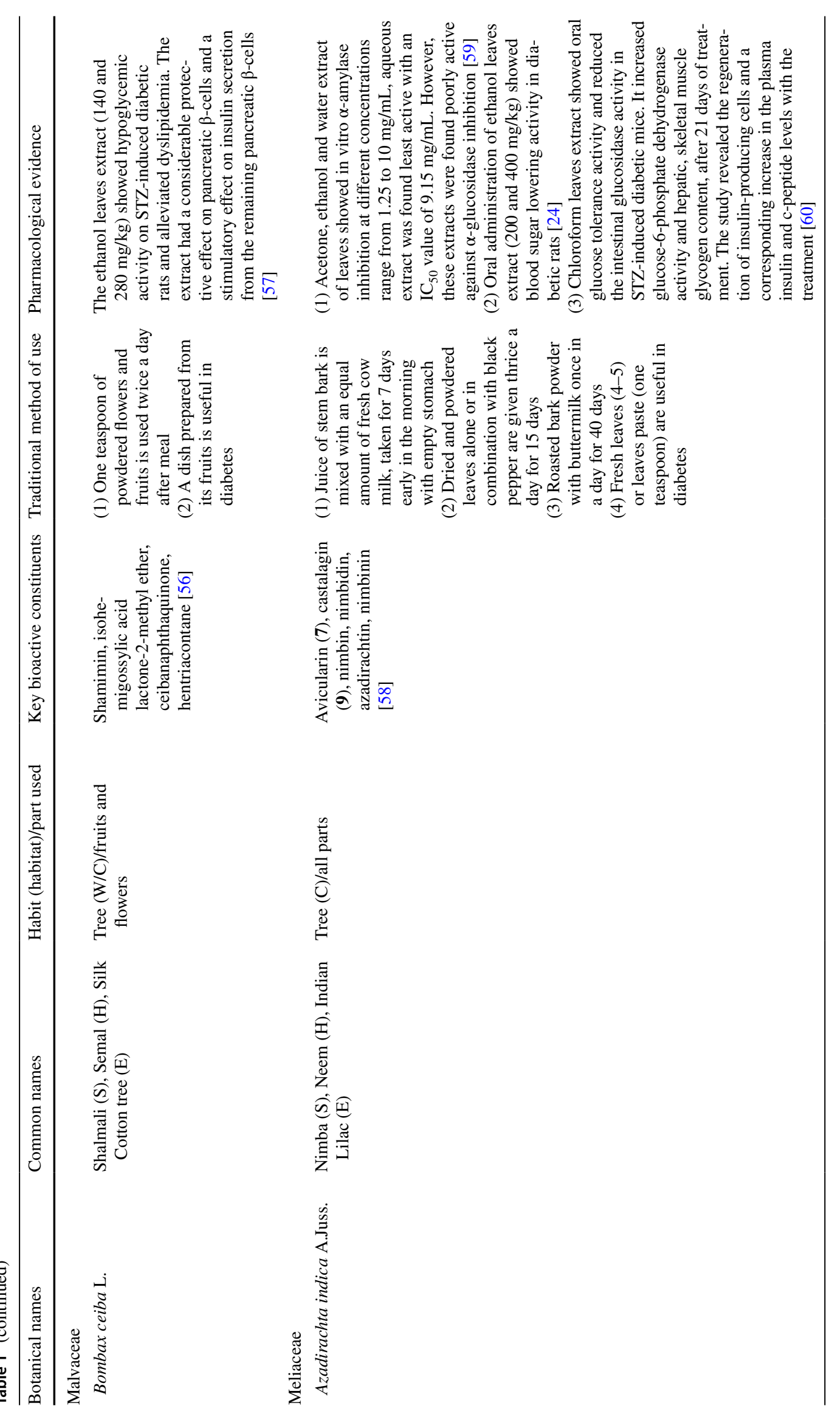




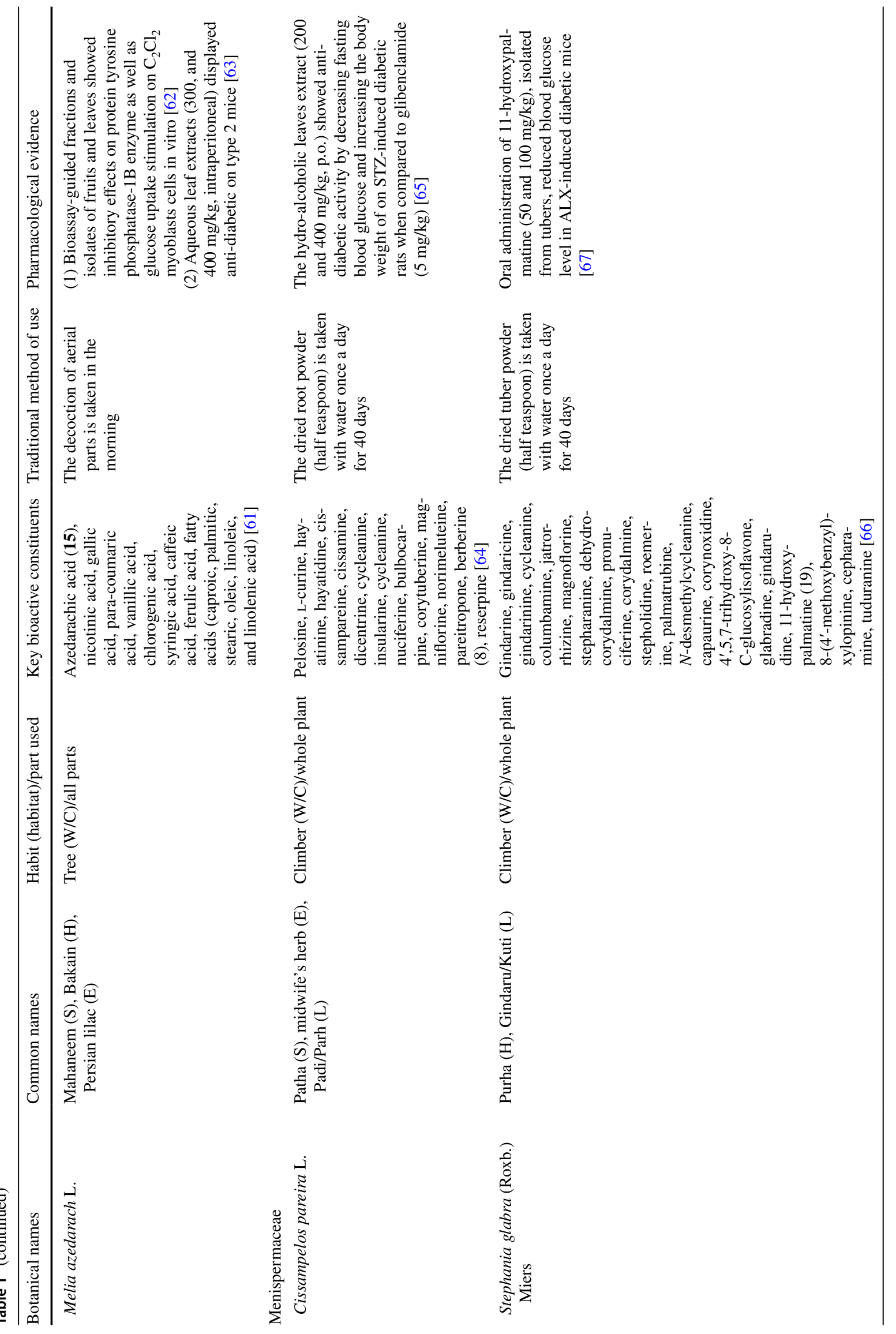




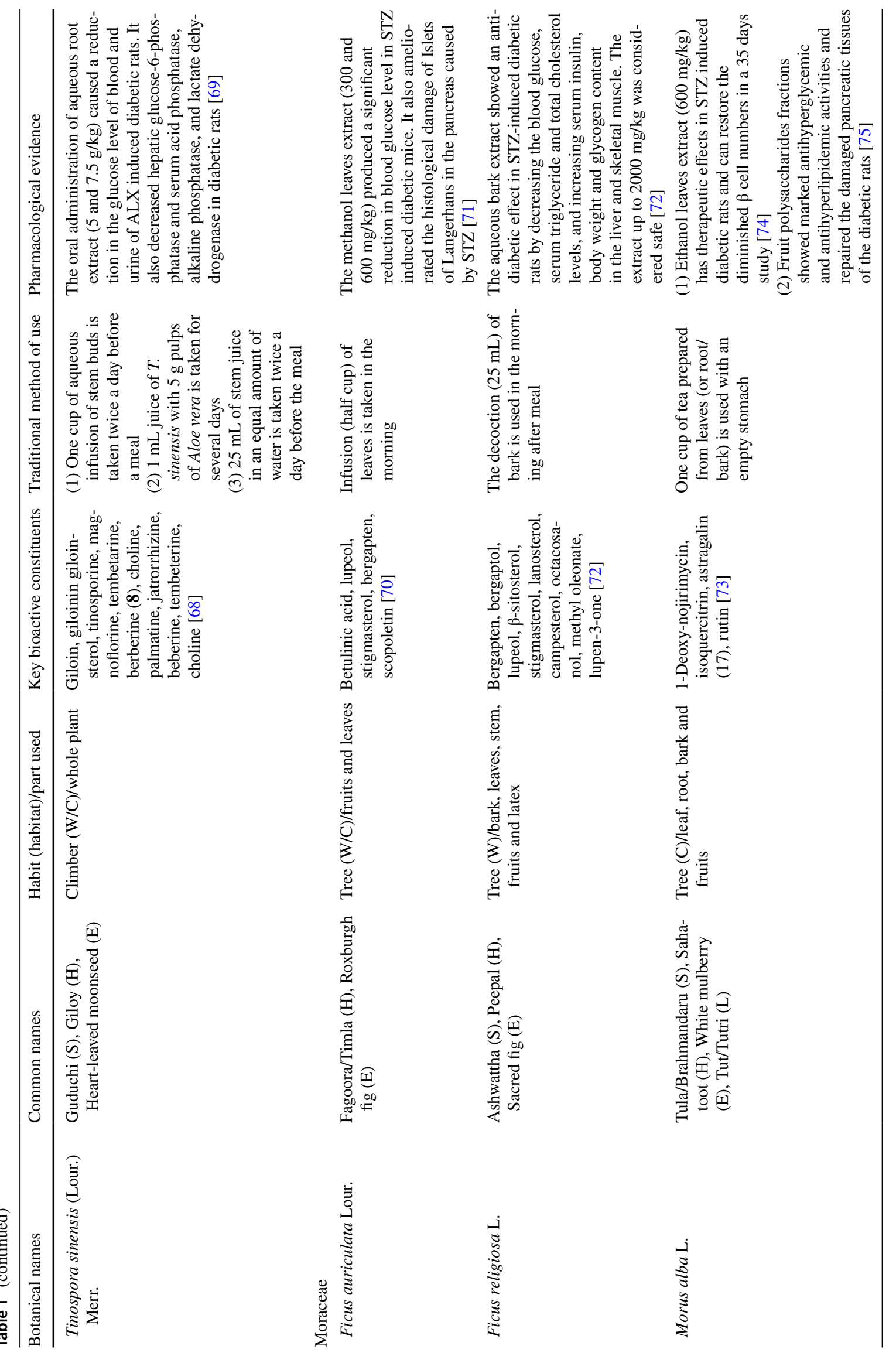




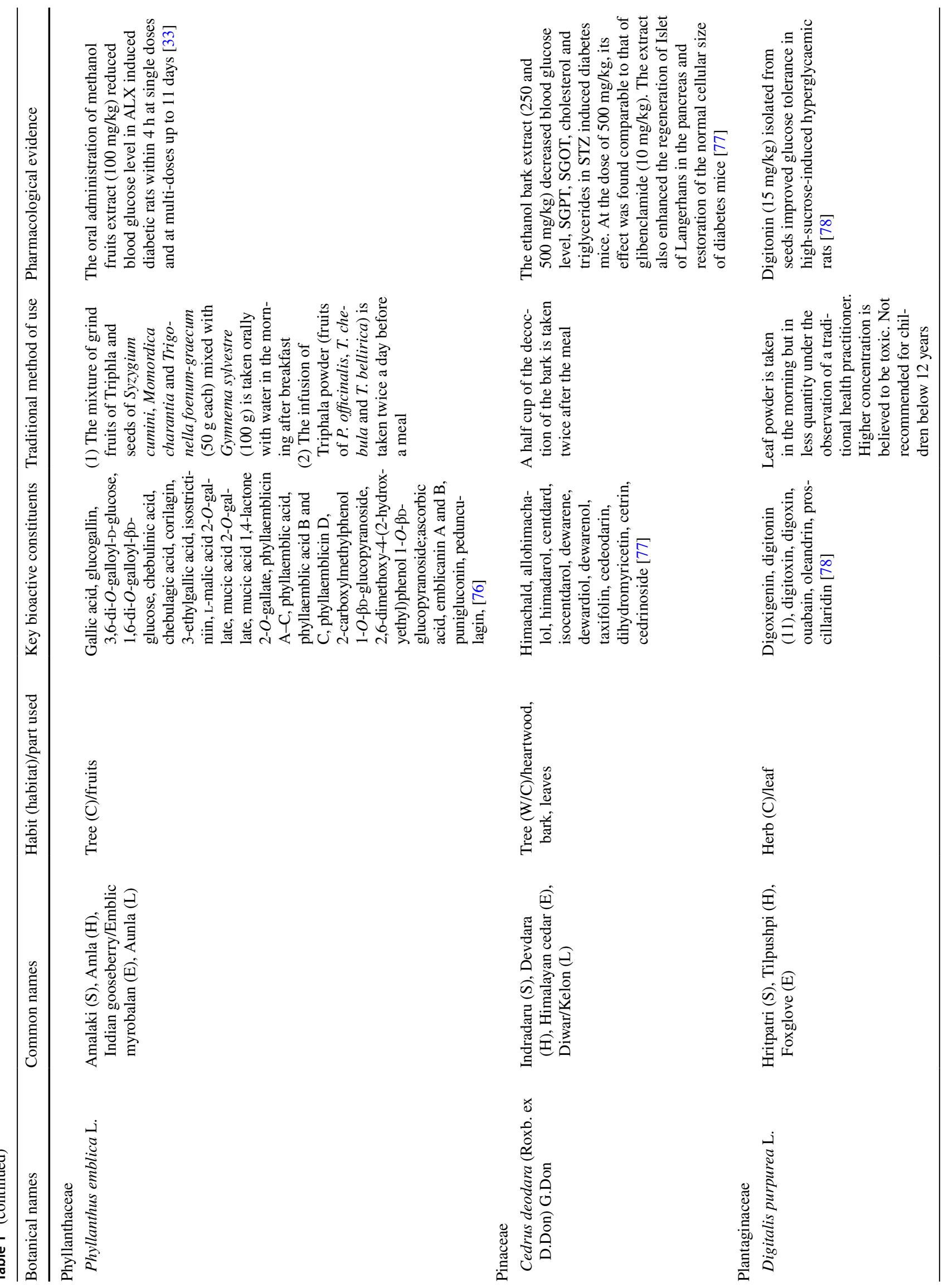




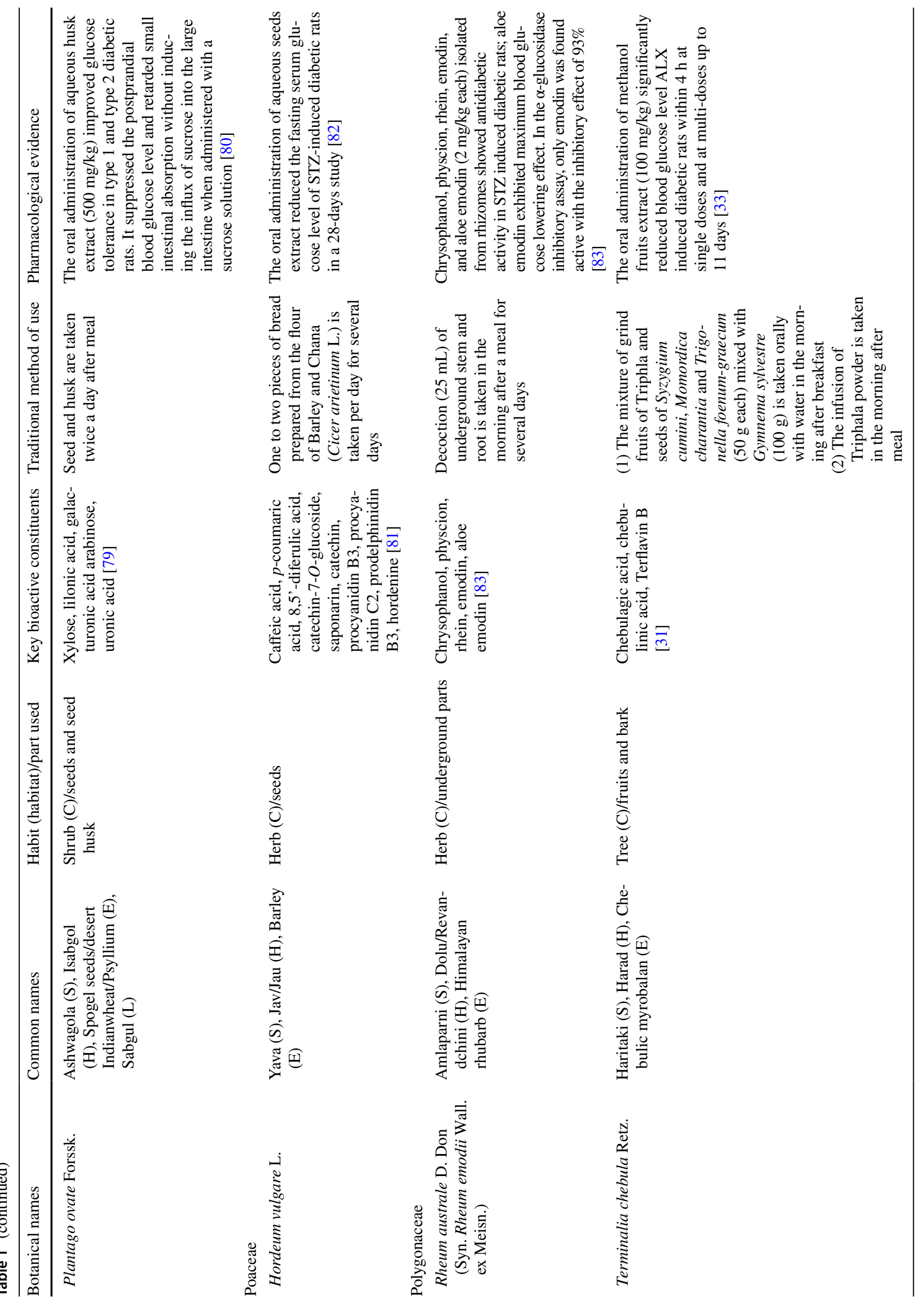




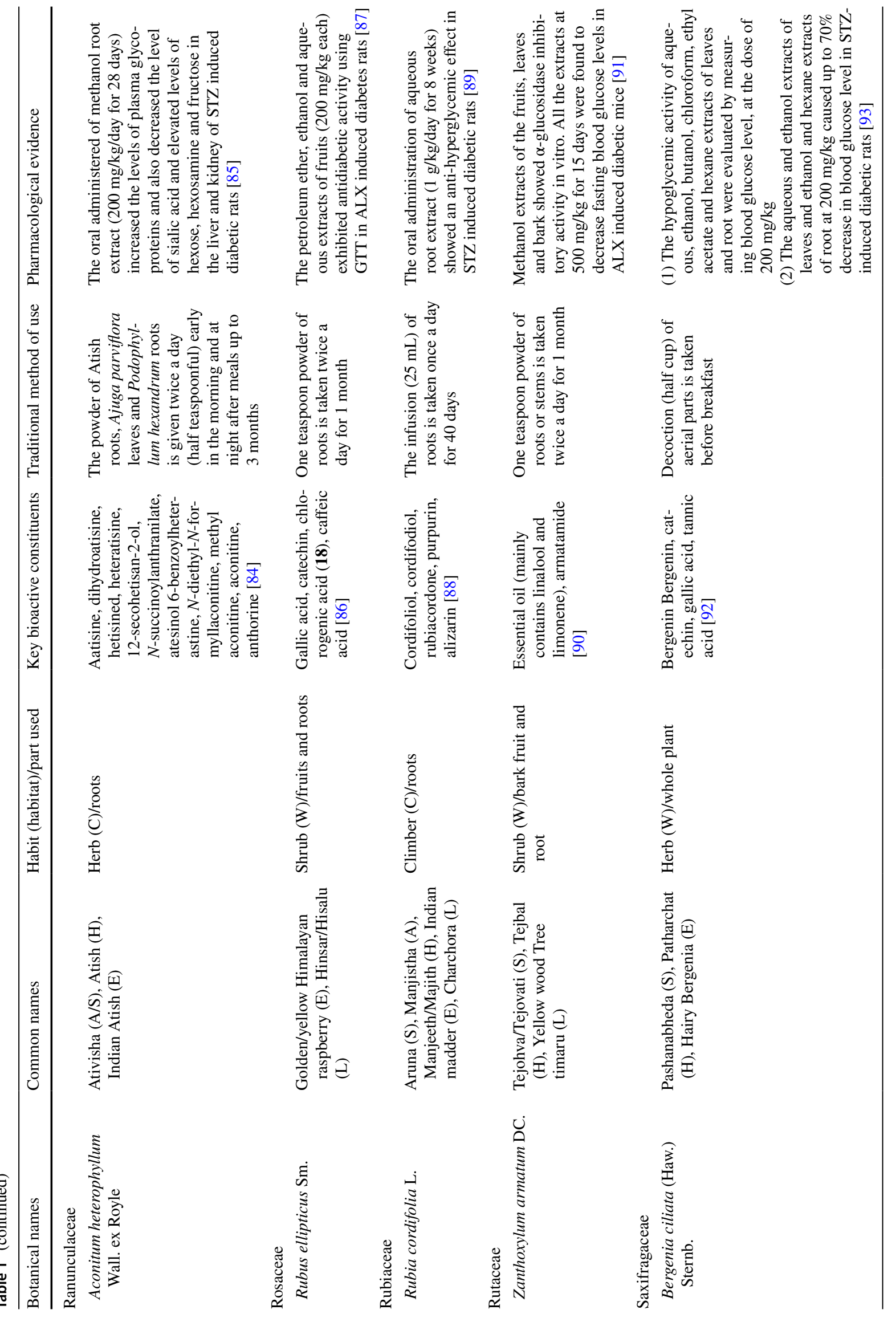




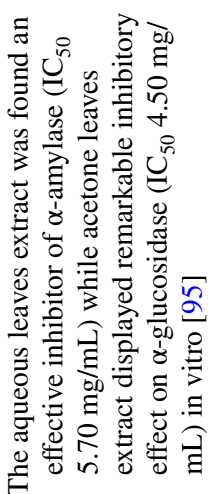

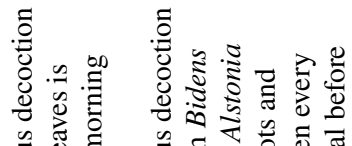

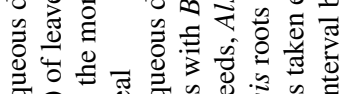

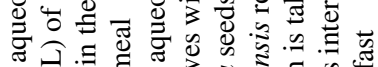

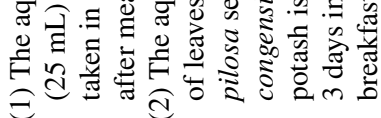

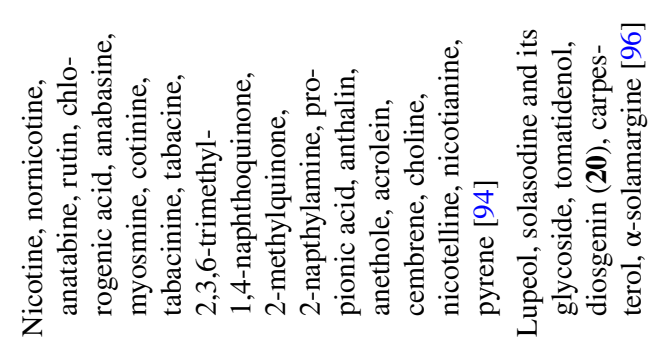

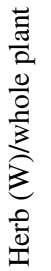

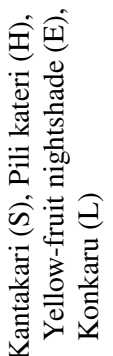

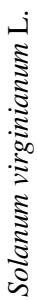

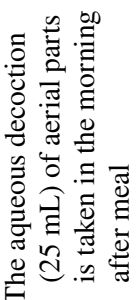

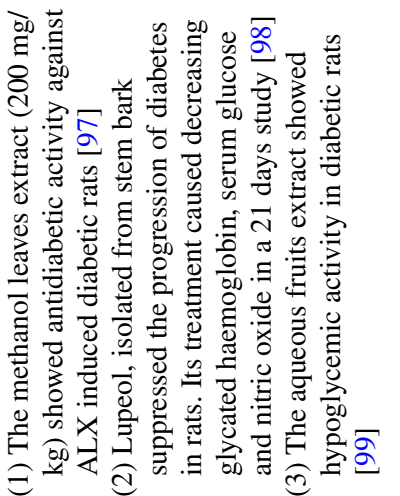

할

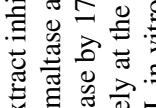

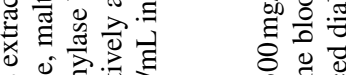

s o

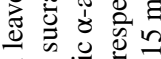

o w

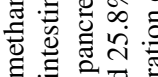

政

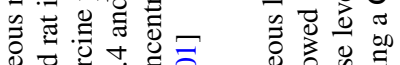

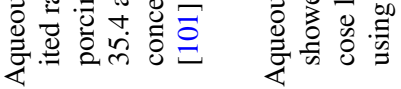

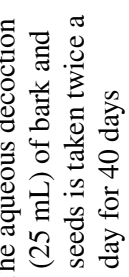

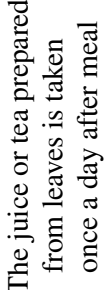
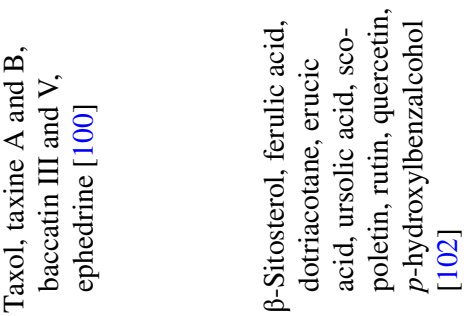

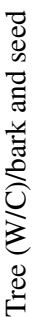

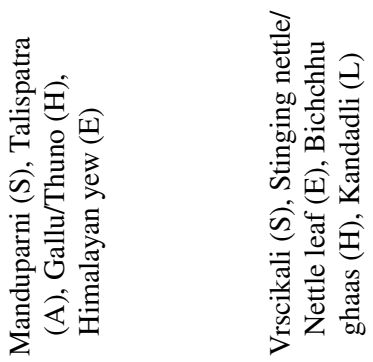




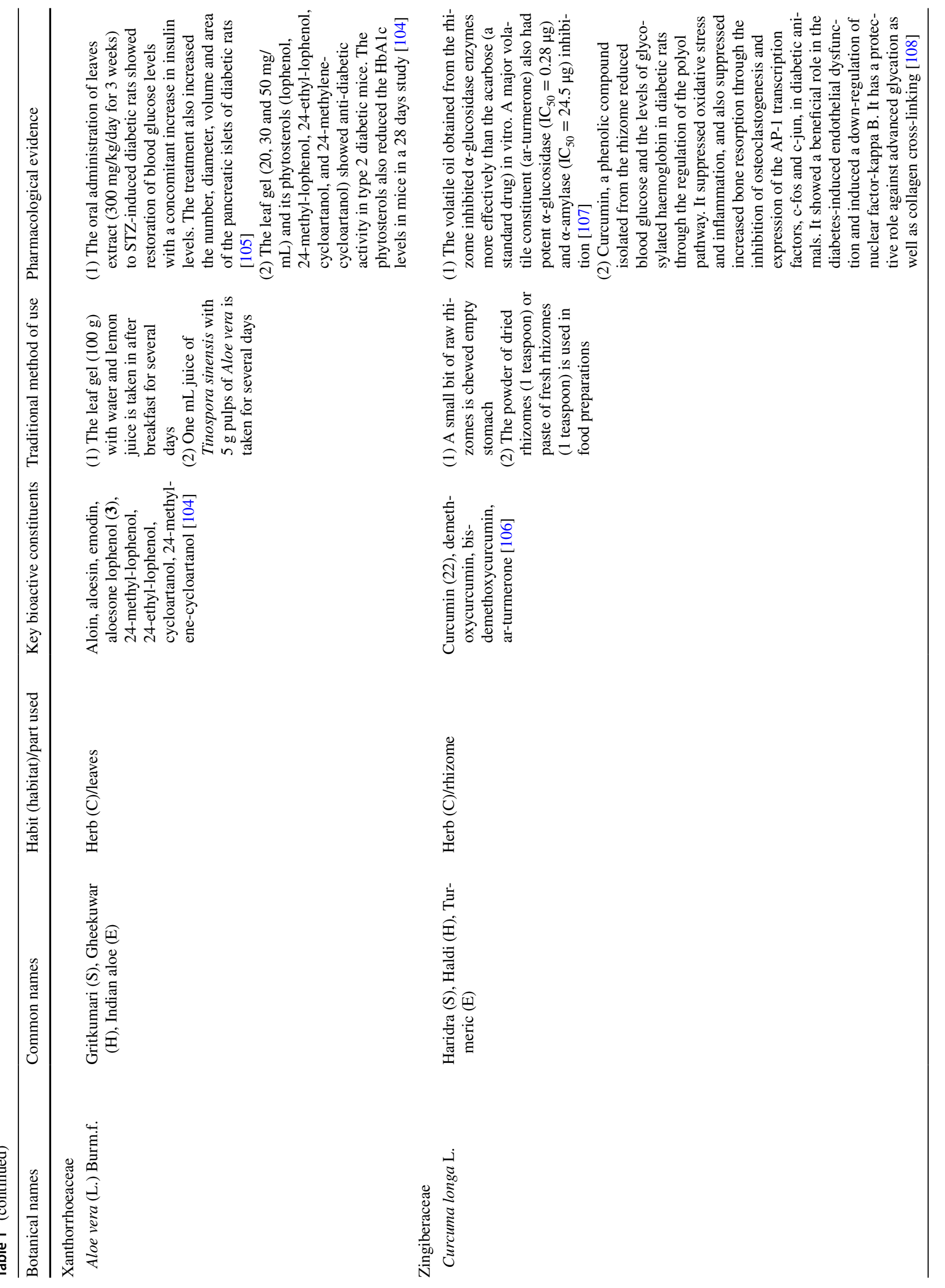




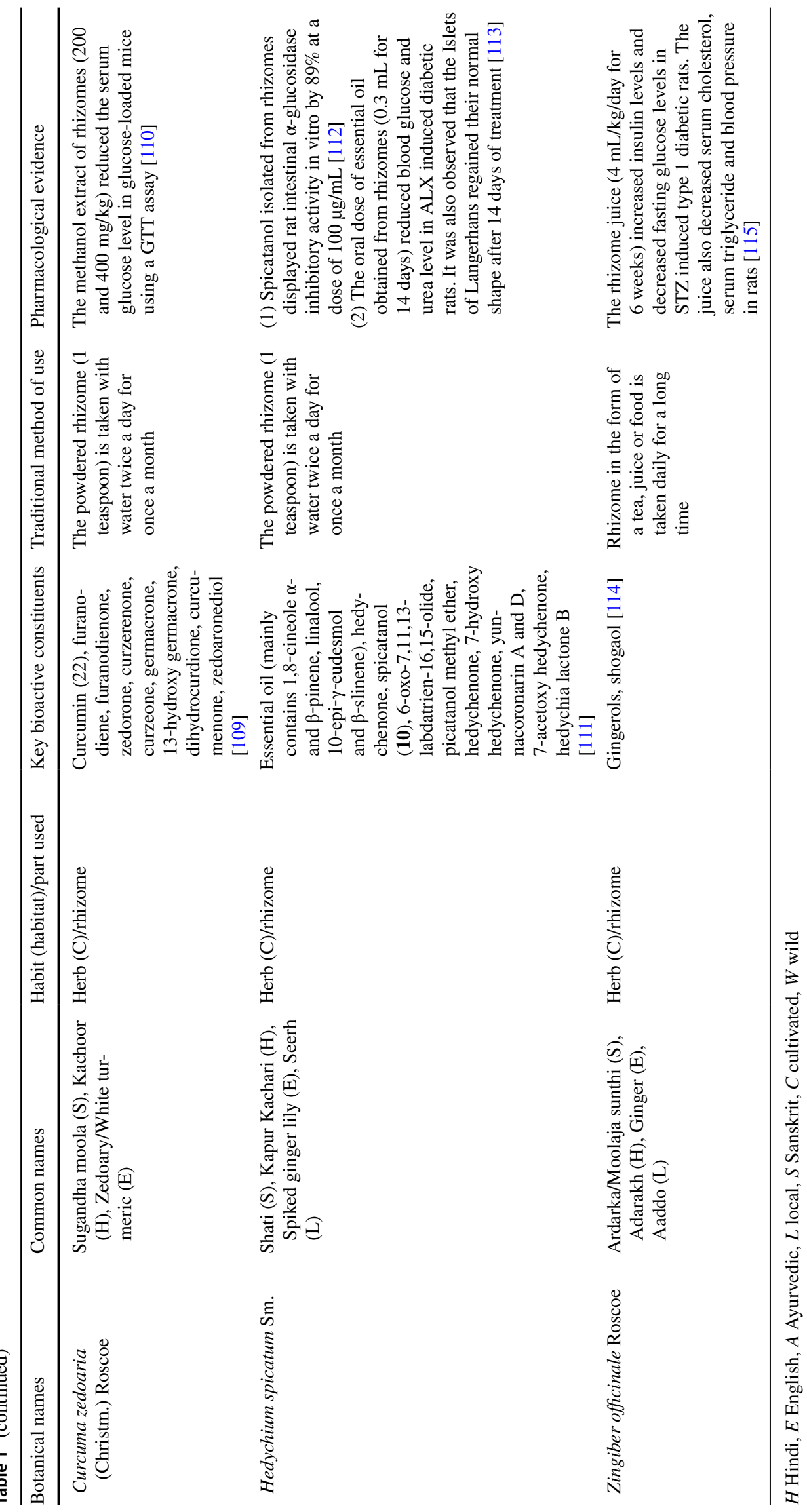


Fig. 2 Selected antidiabetic compounds reported from surveyed plants
S-Methylcysteine sulfoxide (1)

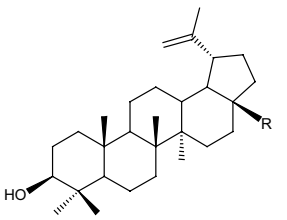

Betulin $\left(\mathrm{R}=\mathrm{CH}_{2} \mathrm{OH}\right)(4)$ Betulinic acid $(\mathrm{R}=\mathrm{COOH})(\mathbf{5})$

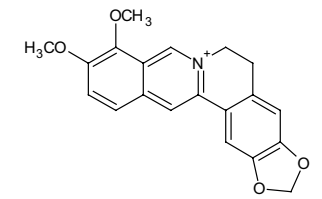

Berberine (8)

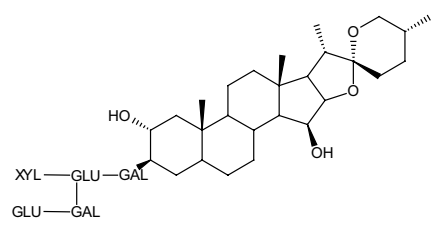

Digitonin (11)<smiles></smiles>

Vasicine $(\mathrm{R}=\mathrm{H})(\mathbf{1 3})$ Vasicinol $(\mathrm{R}=\mathrm{OH})(\mathbf{1 4})$

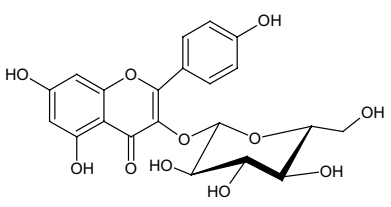

Astragalin (17)<smiles>C[C@H]1CC[C@]2(OC1)O[C@@H]1CC3C4CC=C5C[C@@H](O)CC[C@]5(C)[C@H]4C[C@]3(C)CC[C@]12C</smiles>

Diosgenin (20)<smiles>C=CCS(=O)CC(N)C(=O)O</smiles>

Alliin (2)

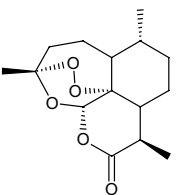

Artemisinin (6)

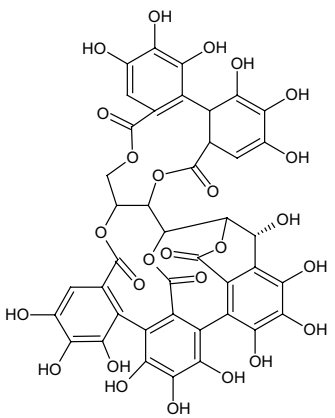

Castalagin (9)<smiles>CC(C)CCC[C@H](C)C1CCC2C3=CC[C@H]4C(C)[C@@H](O)CCC4(C)C3CCC21C</smiles>

Lophenol (3)<smiles></smiles>

Avicularin (7)<smiles>CC1=CC(=O)C2C(C)(C)CCCC2(C)C1/C=C/C1=CC(=O)O[C@@H]1O</smiles>

Spicatanol (10)

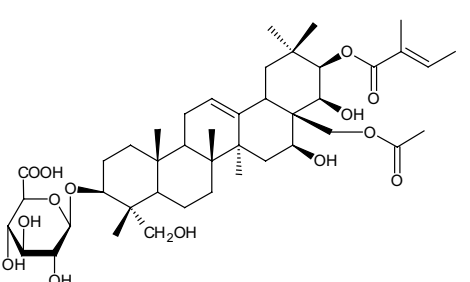

Gymnemic acid (12)<smiles>CC(C)=CCCC(C)C1C(O)CC2(C)C3=CCC4C(C)(C)[C@@H](O)CCC4(C)[C@H]3C(O)CC12C</smiles>

Azedarachic acid (15)

23<smiles>CC1=C(O)C(=O)OC1C</smiles>

Sotolone (16)<smiles>O=C(/C=C/c1ccc(O)c(O)c1)O[C@@H]1CC(O)(O)C[C@H](O)[C@H]1O</smiles>

Chlorogenic acid (18)

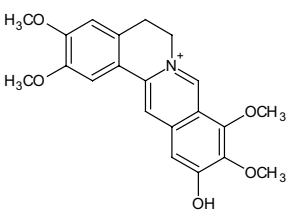

11-Hydroxypalmatine (19)<smiles></smiles>

Trigonelline (21)<smiles>COC1=CC(/C=C/C(=O)CC(=O)/C=C/c2ccc(O)c(OC)c2)CC=C1O</smiles>

Curcumin (22) 


\section{Existing Antidiabetic Formulations Prepared from Surveyed Plants}

A number of medicinal plants found in the present study site are already used for the treatment of diabetes. Various formulations prepared from such plants are available in the market and frequently prescribed by Ayurvedic practitioners. Of these, few selected formulations based on the medicinal plants of the present survey are given in Table 2 .

\section{Market Demand for Selected Surveyed Plants}

Presently, herbal drugs and cosmetics have a huge market worldwide mainly in Asian countries. In India, the National Medicinal Plants Board (Govt. of India) is the whole sole agency for monitoring and documenting the Indian medicinal plants. The agency is involved in the cultivation and promotion of medicinal plants to ensure the availability of quality raw material for the manufacturing of herbal drugs and cosmetics.

A. heterophyllum, commonly known as Atis or Ativisha, has about 100-200 metric tons annual trade in India. The plant is mainly cultivated in India, Nepal and Pakistan. Due to its diverse therapeutical applications in microbial infections, fever, vomiting, coughs, diarrhoea, and indigestion, it is used as one of the ingredients of many Ayurvedic formulations including Bala chaturbhadrika churna, Chandraprabha vati, Khadiradi gutika, Kutaj ghan vati, Lakasminarayana rasa, Mahavisagarbha taila, Panchkrita guggulu ghrita, Rasnairandadi kashayam, Rasnairandadi kvatha churna, Rodhrasava, Siva gutika and Sudarshana churna, etc. [116]. Kachnar (B. variegata), which is used in wounds, ulcer, thyroid problems, cervical lymphadenitis and rectal prolapse, is an important ingredient of Kachnar guggulu, Chitrakadi taila, Chandanasava, Ushirasava, Gandamala kandana rasa and Mutra sangrahaniya kwata. According to the National Medicinal Plants Board, Ministry of AYUSH, Government of India, its current market demand is also about 100-200 metric tons annually. Talispatra (T. baccata) and Devadaru (C. deodara) are also important Ayurvedic medicinal plants and their annual market demand is 100-200 and 1000-2000 metric tons, respectively.

Devadaru (C. deodara), an Ayurvedic remedy for inflammation, fever, pruritus, infested wounds, allergic rhinitis, constipation, drowsiness, hiccups, diabetes, cough, skin disease, rheumatoid arthritis and blood disorders, has been used in the preparation of khadirarista, dasamularista, devadarvarista, mrtasanjivanisura, karpuradyarka, pramehamihaira taila, chandanadi churna, narayana taila, pradarantaka lauha, vataraktanaka lauha, mahavisagarbha taila, anu oil, maharasnadi kashayam, devdarvadi kashaya, chandraprabha vati and pushkaramoolasav formulations. On the other hand,

Table 2 Market formulations for diabetes treatment prepared from surveyed plants

\begin{tabular}{|c|c|}
\hline Formulation & Ingredients \\
\hline $\begin{array}{l}\text { Amritamehari churna (classical medicine), Bio-gynema capsules, } \\
\text { Glukostat capsules, Diabegon capsules, Debix, Diaxinol (patent } \\
\text { drugs) }\end{array}$ & G. sylvestre \\
\hline Chandraprabha vati (classical drug) & $\begin{array}{l}\text { B. aristata, } C \text {. deodara, } C \text {. longa, } H \text {. vulgare, } P . \text { emblica, } \text { T. bellirica, } T \text {. } \\
\text { chebula, } \text {. sinensis, } Z \text {. officinale, A. heterophyllum }\end{array}$ \\
\hline Dhanvantaram-ghritam (classical medicine) & M. philippensis \\
\hline Diabeco (patent drug) & O. tenuiflorum \\
\hline Diabecon (patent drug) & $\begin{array}{l}\text { B. aristata, } C . \text { longa, G. sylvestre, } P \text {. emblica, } \text {. bellirica, } \text { T. sinensis, } A \text {. } \\
\text { vera, } \text { A. racemosus }\end{array}$ \\
\hline Diacare capsules (patent drug) & C. longa, P. emblica, O. tenuiflorum, T. chebula \\
\hline Diasulin (patent drug) & C. longa, G. sylvestre, P. emblica, $T$. sinensis, T. foenum-graecum \\
\hline Fenfuro (patent drug) & T. foenum-graecum \\
\hline Garlic capsules (patent drug) & A. sativum \\
\hline Karnim plus (patent drug) & Z. officinale, A. indica, O. tenuiflorum \\
\hline Kishora guggulu (classical medicine) & P. emblica, T. bellirica, T. chebula, T. sinensis \\
\hline Limit capsules (patent drug) & T. foenum-graecum, G. sylvestre \\
\hline Mandoor-Vatak & C. deodara \\
\hline Neem capsules (patent drug) & A. indica \\
\hline Nisakathakadi kashayam, Nishamalaki chunra (classical medicine) & C. longa \\
\hline Sarivadyasava (classical medicine) & F. religiosa, $H$. spicatum \\
\hline Triphla (classical medicine) & P. emblica, T. bellirica, T. chebula \\
\hline
\end{tabular}


T. baccata, useful in cancer, blood disorders, skin disease, burning sensation, worms and papules, is an ingredient of Mahanarayana Taila and Bala Taila. U. dioica, helpful in kidney stones, allergies, anaemia, osteoarthritis, hay fever, burns, internal bleeding, nosebleeds, urination problems, gout, sciatica, neuralgia, haemorrhoids and hair problems, is a part of various formulations including vishatinduka taila and caffeine-free herbal tea. Its market demand is comparatively lesser (about $<10$ metric tons annually) than other important Ayurvedic herbs.

In view of the market demand, a number of antidiabetic plants are cultivated in India including in the present study area. The main cultivated medicinal plants of the study area are $Z$. officinale, $C$. longa, A. cepa, A. sativum, A. graveolens, $C$. zedoaria, $H$. vulgare and $T$. foenum-graecum. The trade of $Z$. officinale and $C$. longa rhizomes in Indian market is about 2000-5000 and 1000-2000 metric tons, respectively. Z. officinale is used in the formulation of Trikatu churna, Ardraka khandavaleha, Sarassvatarista, Adraka ghrita, Shothaghna lepa, Saubhagya shunti and Guladrakm. India is known as one of the largest producers of ginger and turmeric in the world. Particularly in Chakrata, both of these plants are cultivated at large scale and considered as an important source of income. Similarly, other medicinal plants such as $A$. vera, $P$. emblica (> 10,000 metric tons), T. chebula (5000-10,000 metric tons), M. piperita, A. racemosus, A. indica, J. adhatoda, T. bellirica (2000-5000 metric tons), O. tenuiflorum (2000-3000 metric tons), $B$. aristata, T. sinensis, $R$. cordifolia, B. ciliata, O. gratissimum (1000-2000 metric tons), S. virginianum, T. foenumgraecum, V. negundo, G. sylvestre (500-1000 metric tons), H. spicatum, H. vulgare, A. cepa, A. sativum, Z. armatum, $C$. roseus, C. zedoaria, F. religiosa (200-500 metric tons), $B$. prionitis, R. emodii and M. azedarach (100-200 metric tons) are cultivated in the study region with high market demand.

\section{Mechanism of Actions of Surveyed Plants and Their Bioactives}

Various earlier research studies reported the possible mechanisms of action shown by the antidiabetic plants as well as their bioactive constituents described in the present paper. $A$. vera and its phytosterols, i.e. lophenol, 24-methyl-lophenol, 24-ethyl-lophenol, cycloartanol and 24-methylene-cycloartanol shows glucose lowering effect through effectively decrease gluconeogenesis and lipogenesis processes. This activity predominantly appears to be mediated by AMPK and PPAR receptors and is accompanied mainly by inhibition of PEPCK and G6P genes expression or inhibition of ACC and FAS enzymatic activities hence reduce hepatic glucose output [104]. Moreover, the hypoglycemic effect of aloes and other bitter principles may be mediated through stimulating synthesis and/or release of insulin from the $\beta$-cells of Langerhans [117].

Berberine, an active principle of $B$. aristata was found to alter glucose metabolism through the stimulation of glycolysis via increasing glucokinase activity, increasing insulin secretion, and suppressing hepatic gluconeogenesis and adipogenesis [118-120]. Similarly, a bioactive molecule $S$-methycystein sulphoxide found in $A$. cepa regulates the enzyme Glucokinase/Hexokinase and stimulates glucose utilization and insulin secretions [121]. On the other hand, quercetin, another bioactive of $A$. cepa increases glucosestimulated insulin secretion through an ERK1/2 pathway which improves liver and pancreas functions by enabling the recovery of cell proliferation through the inhibition of Cdkn1a expression [122].

Curcuma longa and its active molecule curcumin increase the islet viability and delay islet ROS production in animals [123]. Curcumin treatment also increases the number of small pancreatic islets and decreases lymphocyte infiltration in pancreatic islets [124]. The intervention of a curcumin-rich extract improves $\beta$-cell functions, indicated by an increased HOMA- $\beta$ and reduced C-peptide in a study conducted by Chuengsamarn et al. [125]. The molecule itself plays antioxidant defence by induction of the expression of HO-1, glutathione subunit, and NAD(P)H:quinone oxidoreductase 1 and increased basal insulin secretion in human islet [126].

Artemisia roxburghiana as well as its bioactives, such as artemisinin, betulinic acid and betulin, act as protein tyrosine phosphatases inhibitor. Through this mechanism, they are known to enhance insulin receptor phosphorylation and stimulate glucose uptake into cells. On the other hand, its flavonoids inhibit cAMP phosphodiesterase which is a modulator of insulin secretion [37]. G. sylvestre has been reported to interact with glyceraldehyde-3-phosphate dehydrogenase, a key enzyme in the glycolysis pathway. In addition, its extract stimulates insulin secretion from human islets [127] and regenerates pancreatic $\beta$-cell in diabetic animals [128]. A leaves extract containing gymnemic acids as a bioactive suppresses the elevation of blood glucose level by inhibiting glucose uptake in the intestine [129]. Gulfraz et al. [15] reported that $J$. adhatoda extract increases the level of insulin in diabetic rats. It brings antihyperglycaemic action perhaps by potentiation of pancreatic secretion of insulin from $\beta$-cell of islets or due to enhanced transport of blood glucose to peripheral tissue.

Morus alba has found to possess antihyperglycemic and antihyperlipidemic activities by activating the IRS-1/PI3K/ Glut-4 signalling pathway in skeletal muscles and hence increases peripheral glucose uptake [130]. It interferes with the activity of $\alpha$-amylase that exhibited an effective strategy to lower the levels of hyperglycemia through the 


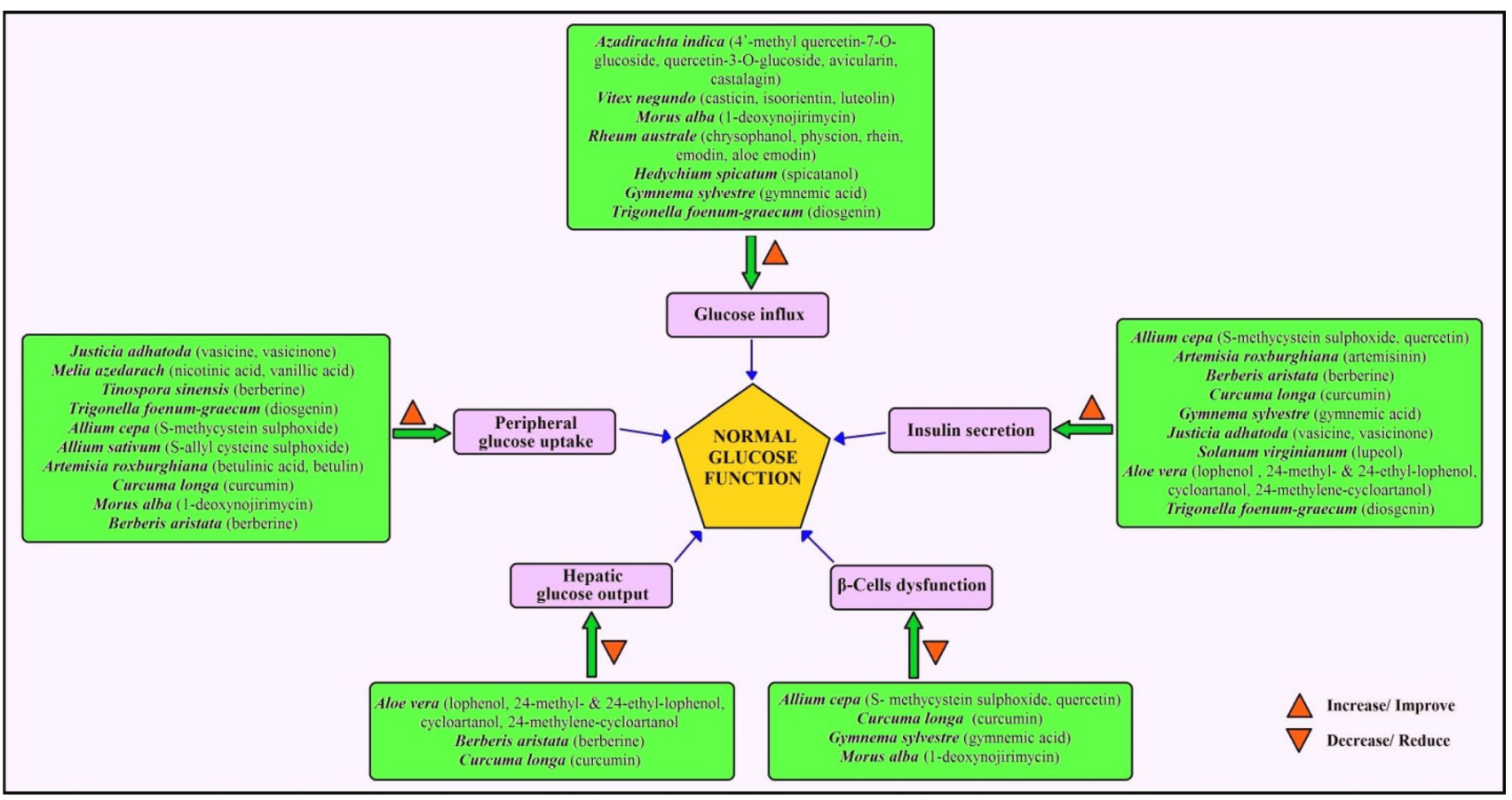

Fig. 3 Schematic diagram showing antidiabetic mechanisms of selected surveyed plants and their bioactives

control of starch breakdown [131]. In addition to inhibiting $\alpha$-amylase, it reduces glucose level via scavenging of ROS and regenerating $\beta$-cell [132]. M. azedarach decreases blood glucose via inhibition of protein tyrosine phosphatase $1 \mathrm{~B}$ (PTP1B) enzyme activity and stimulation of glucose uptake rats [133]. T. sinensis was also found to inhibit PTP1B activity and stimulate the glucose uptake [134]. $R$. australe and its active molecules rhapontigenin, desoxyrhaponticin and desoxyrhapontigenin inhibit the mammalian $\alpha$-glucosidase [135], whereas $V$. negundo inhibits $\alpha$-amylase to decrease blood glucose level [136]. T. foenum-graecum stimulates insulin secretion at all levels of the cellular organization since the cells are more sensitive to insulin and increase in the number of insulin receptor sites to burn cellular glucose at high fibre diet in rats [137]. A schematic diagram of the antidiabetic mechanisms of selected plants/bioactives is shown in Fig. 3.

\section{Status of the Medicinal Plants of Chakrata Region}

Various plants in the Chakrata region are rare and only grown as wild, their cultivation is still a big challenge. The surveyed plants were checked in the IUCN Red List [138] for their current status and found that many of them are already included in the list of threatened species. According to the IUCN List, B. variegata, C. deodara, T. baccata and $U$. dioica are identified as the plants of least concern whereas A. heterophyllum and S. hexandrum are reported as an endangered plant. Although many rare plants, including A. heterophyllum, are cultivated in a big scale in India and exported to other countries [139], many other plants of this particular region are also in the stage of vulnerable and their protection is highly needed. Various reports published in past years also highlighted the importance of these plants including their medicinal uses, market demand and current status [140-143].

\section{Conclusion}

The Chakrata region (Jaunsar-Bawar Hills) is one of the sites of the rich diversity of medicinal plants in Uttarakhand, India. Most of the areas of this region are covered by the forests with a very scattered population mainly the tribal community. The population is mainly depends on folk medicine due to limited hospitals in the region. These people prefer to consult the local traditional healers or elderly person in the family for the treatment, and only moved to the distantly located hospitals in case of any serious health trouble.

There are various nurseries, such as Deovan and Khoonigarh, in the region established by the Forest Department (Govt. of Uttarakhand) to cultivate valued medicinal and other economic plants including some fruits and timber yielding plants. In addition, the natives also cultivate several 
useful plants to generate the economy for their survival. There is good support of the local government to encourage them by providing quality seeds, fertilisers and tools in subsidised rates.

The present study site has numerous antidiabetic plants found as wild such as B. aristata, J. adhatoda, C. pareira, $S$. glabra, A. roxburghiana, T. baccata, etc. This region is also popular for cultivating many rare medicinal plants such as $A$. heterophyllum, S. hexandrum and B. variegata. Thus, with the help of cultivation in a big scale, the threatened plants in this region can be conserved for the future. The overharvesting of the medicinal plants can also be minimised by investigating their bioactive compounds and synthesising them in the laboratories to fulfil the market demand of such plants. This approach may also be worthy in case a particular medicinal plant becomes extinct in the future, its drug/ formulation will be always available for the treatment of a particular disease.

Acknowledgement This work was financially supported by National Medicinal Plants Board, Ministry of AYUSH, Govt. of India (Grant No. Z.18017/187/CSS/R\&D/UK-01/2017-18-NMPB-IV A).

\section{Compliance with Ethical Standards}

Conflict of interest The authors declare no conflict of interests.

Open Access This article is distributed under the terms of the Creative Commons Attribution 4.0 International License (http://creativeco mmons.org/licenses/by/4.0/), which permits unrestricted use, distribution, and reproduction in any medium, provided you give appropriate credit to the original author(s) and the source, provide a link to the Creative Commons license, and indicate if changes were made.

\section{References}

1. A.D. Chapman, Numbers of Living Species in Australia and the World, 2nd edn. (Australian Government, Department of the Environment, Water, Heritage and the Arts, 2009)

2. P. Singh, S.S. Dash, Plant Discoveries 2013-New Genera, Species and New Records (Botanical Survey of India, Kolkata, 2014)

3. U. Dhar, R.S. Rawal, J. Upreti, Biol. Conserv. 95, 57-65 (2000)

4. World Health Organization, Global Report on Diabetes (WHO Press, Geneva, 2016). http://www.who.int. Accessed 21 May 2018

5. S.P. Jain, H.S. Puri, J. Ethnopharmacol. 12, 213-222 (1984)

6. The Plant List. Version 1.1. http://www.theplantlist.org/. Accessed 1 Jan 2013

7. S. Jana, G.S. Shekhawat, Anethum graveolens: an Indian traditional medicinal herb and spice. Pharmacogn. Rev. 4(8), 179-184 (2010)

8. N. Mishra, Vet. World 6, 502-507 (2013)

9. M. Setorki, M. Rafieian-Kopaei, A. Merikhi, E. Heidarian, N. Shahinfard, R. Ansari, H. Nasri, N. Esmael, A. Baradaran, Int. J. Prev. Med. 4, 889-895 (2013)

10. N.M. Ahmadi, Iran. J. Med. Aromat. Plants 24, 333-341 (2008)

11. M.T. Goodarzi, I. Khodadadi, H. Tavilani, E.A. Oshaghi, J. Trop. Med. 2016, Art ID 1098916 (2016)
12. F. Haidari, N. Seyed-Sadjadi, M. Taha-Jalali, M. MohammedShahi, Saudi Med. J. 32, 695-700 (2011)

13. K. Singh, D. Sharma, R.S. Gupta, Asian J. Pharm. Clin. Res. 10, 22-29 (2017)

14. R. Dheer, P. Bhatnagar, Indian J. Pharmacol. 42, 70-73 (2010)

15. M. Gulfraz, A. Ahmad, M.J. Asad, U. Afzal, M. Imran, P. Anwar, R.U. Qureshi, Afr. J. Biotechnol. 10, 6101-6106 (2011)

16. M.S.H. Akash, K. Rehman, S. Chen, Nutrition 30, 1128-1137 (2014)

17. S.K. Sood, R. Bhardwaj, T.N. Lakhanpal, Ethenic Indian Plants in Cure of Diabetes (Scientific Publishers, Jodhpur, 2005), pp. $17-18$

18. I.M.T. Eldin, E.M. Ahmed, E.H. Abd, Environ. Health Insights (2010). https://doi.org/10.4137/EHI.S5540

19. C.G. Sheela, K. Kumud, K.T. Augusti, Planta Med. 61, 356-357 (1995)

20. N. Martins, S. Petropoulos, I.C.F.R. Ferreira, Food Chem. 211, 41-50 (2016)

21. A. Eidi, M. Eidi, E. Esmaeili, Phytomedicine 13, 624-629 (2006)

22. A. Kattel, J.A. Maga, Dev. Food Sci. 37, 919-928 (1995)

23. K. Rasineni, R. Bellamkonda, S.R. Singareddy, S. Desireddy, Pharmacogn. Res. 2, 195-201 (2010)

24. R.R. Chattopadhyay, J. Ethnopharmacol. 67, 367-372 (1999)

25. A.B.A. Ahmed, A.S. Rao, M.V. Rao, Phytomedicine 17, 10331039 (2010)

26. S. Alok, S.K. Jain, A. Verma, M. Kumar, A. Mahor, M. Sabharwal, Asian Pac. J. Trop. Dis. 3, 242-251 (2013)

27. J.M.A. Hannan, L. Marenah, L. Ali, B. Rokeya, P.R. Flatt, Y.H. Abdel-Wahab, J. Endocrinol. 192, 159-168 (2007)

28. R.K. Suman, M.K. Borde, I.R. Mohanty, U. Maheshwari, Y.A. Deshmukh, J. Clin. Diagn. Res. 10, 13-18 (2016)

29. J. Singh, P. Kakkar, J. Ethnopharmacol. 123, 22-26 (2009)

30. R. Chawla, R. Arora, R.K. Sagar, S. Singh, S.C. Puri, R. Kumar, S. Singh, A.K. Sharma, J. Prasad, H.A. Khan, R.K. Sharma, K.L. Dhar, M. Spiteller, G.N. Qazi, Z. Naturforsch C 60, 728-738 (2005)

31. I.E. Cock, Inflammopharmacology 23, 203-229 (2015)

32. V. Kasabri, P.R. Flatt, Y.H. Abdel-Wahab, Br. J. Nutr. 103, 212 217 (2010)

33. M.C. Sabu, R. Kuttan, J. Ethnopharmacol. 81, 155-160 (2002)

34. S.Z. Haider, M. Mohan, H.C. Andola, Pharmacogn. Res. 6, 257 (2014)

35. W. Ahmad, I. Khan, M.A. Khan, M. Ahmad, F. Subhan, N. Karim, J. Ethnopharmacol. 151, 618-623 (2014)

36. D. Shahwar, M.A. Raza, V.U. Ahmad, J. Chem. Soc. Pak. 35, 135-138 (2013)

37. M.R. Shah, S.M. Ishtiaq, S. Hizbullah, A. Habtemariam, A. Zarrelli, S. Muhammad, I. Collina Khan, J. Enzyme Inhib. Med. Chem. 31, 563-567 (2016)

38. Z. Hussain, A. Waheed, R.A. Qureshi, D.K. Burdi, E.J. Verspohl, N. Khan, M. Hasan, Phytother. Res. 18, 73-77 (2004)

39. M. Alizadeh, M. Aghaei, I. Sharifian, M. Saadatian, Electron. J. Environ. Agric. Food Chem. 11, 493-496 (2012)

40. G. Sravanthi, G.N. Reddy, R. Gunnam, J.V. Suresh, G. Harika, World J. Pharm. Biotechnol. 2, 16-21 (2015)

41. M. Gangwar, R.K. Goel, G. Nath, BioMed. Res. Int. 2014, Art. ID 213973 (2014)

42. V. Nandhini, D.V. Doss, Int. J. Pharma Biosci. 4, 653-658 (2013)

43. M. Nikolić, K.K. Jovanović, T. Marković, D. Marković, N. Gligorijević, S. Radulović, M. Soković, Ind. Crops Prod. 61, 225-232 (2014)

44. J. Angel, S.K. Sailesh, J.K. Mukkadan, J. Clin. Biomed. Sci. 3, 177-181 (2013)

45. R.K. Joshi, Indian J. Pharm. Sci. 75, 457-462 (2013)

46. S.I. Okoduwa, I.A. Umar, D.B. James, H.M. Inuwa, Medicines 4, 73 (2017) 
47. R.B. Semwal, D.K. Semwal, S.P. Mishra, R. Semwal, Nat. Prod. J. 5, 199-205 (2015)

48. S. Parasuraman, S. Balamurugan, P.V. Christapher, R.R. Petchi, W.Y. Yeng, J. Sujithra, C. Vijaya, Pharmacogn. Res. 7, 156 (2015)

49. S.P. Beauchamp, A.T. Bottini, M.C. Caselles, V. Dev, H. Hope, M. Larter, G. Lee, C.S. Mathela, A.B. Melkani, P.D. Millar, M. Miyatake, A.K. Pant, R.J. Raffel, V.K. Sharma, D. Wyatt, Phytochemistry 43, 827-834 (1996)

50. Nirja, Richa, M.L. Sharma, Int. J. Pharm. Sci. Rev. Res. 41, 232-238 (2016)

51. C.J. Zheng, H.Q. Li, S.C. Ren, C.L. Xu, K. Rahman, L.P. Qin, Y.H. Sun, Phytother. Res. 29, 633-647 (2015)

52. D. Dave, M. Mansuri, G. Shah, Saudi J. Med. Pharm. Sci. 4, 226-234 (2018)

53. R. Sundaram, R. Naresh, R. Ranadevan, P. Shanthi, P. Sachdanandam, Eur. J. Pharmacol. 674, 460-467 (2012)

54. Y.A. Kulkarni, M.S. Garud, Biomed. Pharmacother. 83, 122-129 (2016)

55. K.C.N. Venkata, D. Bagchi, A. Bishayee, Mol. Nutr. Food Res. 61, 1600950 (2017)

56. P.H. Chaudhary, S.S. Khadabadi, Pharmacogn. Commun. 2, 1-9 (2012)

57. G.K. Xu, X.Y. Qin, G.K. Wang, G.Y. Xie, X.S. Li, C.Y. Sun, B.L. Liu, M.J. Qin, Chin. J. Nat. Med. 15, 168-177 (2017)

58. T. Lakshmi, V. Krishnan, R. Rajendran, N. Madhusudhanan, Pharmacogn. Rev. 9, 41-44 (2015)

59. M.I. Kazeem, T.V. Dansu, S.A. Adeola, Pak. J. Biol. Sci. 16, 1358-1362 (2013)

60. M. Bhat, S.K. Kothiwale, A.R. Tirmale, S.Y. Bhargava, B.N. Joshi, Evid. Based Complement. Altern. Med. 2011, Art. ID 561625 (2011)

61. R.G. Bitencourt, C.L. Queiroga, G.H.B. Duarte, M.N. Eberlin, L.K. Kohn, C.W. Arns, F.A. Cabral, J. Supercrit. Fluids 95, 355-363 (2014)

62. M.F. Khan, A.K. Rawat, B. Pawar, S. Gautam, A.K. Srivastava, D.S. Negi, Fitoterapia 98, 98-103 (2014)

63. D. Seifu, L.E. Gustafsson, R. Chawla, S. Genet, A. Debella, M. Holst, P.M. Hellström, J. Exp. Pharmacol. 9, 23 (2017)

64. D.K. Semwal, R.B. Semwal, I. Vermaak, A. Viljoen, J. Ethnopharmacol. 155, 1011-1028 (2014)

65. V. Jannu, D.S. Vishal, V.R. Babu, B. Harisha, D.R.C.S. Reddy, Int. J. Pharm. Technol. 3, 3601-3611 (2011)

66. D.K. Semwal, R.B. Semwal, Nat. Prod. Res. 29, 396-410 (2015)

67. D.K. Semwal, U. Rawat, R. Semwal, R. Singh, G.J.P. Singh, J. Asian Nat. Prod. Res. 12, 99-105 (2010)

68. K. Sinha, N.P. Mishra, J. Singh, S.P.S. Khanuja, Indian J. Tradit. Knowl. 3, 257-270 (2004)

69. P. Stanely, M. Prince, V.P. Menon, J. Ethnopharmacol. 70, 9-15 (2000)

70. M.Z.M. Salem, A.Z.M. Salem, L.M. Camacho, H.M. Ali, Afr. J. Microbiol. Res. 7, 4207-4219 (2013)

71. R. Thingbaijam, B.K. Dutta, S.B. Paul, World J. Pharm. Pharm. Sci. 3, 412-427 (2013)

72. P. Deepa, K. Sowndhararajan, S. Kim, S.J. Park, J. Ethnopharmacol. 215, 210-232 (2018)

73. S. Tian, M. Tang, B. Zhao, J. Tradit. Chin. Med. Sci. 3, 3-8 (2016)

74. J. Mohammadi, P.R. Naik, Indian J. Pharmacol. 40, 15-18 (2008)

75. Y. Jiao, X. Wang, X. Jiang, F. Kong, S. Wang, C. Yan, J. Ethnopharmacol. 199, 119-127 (2017)

76. B.C. Variya, A.K. Bakrania, S.S. Patel, Pharmacol. Res. 111, 180-200 (2016)

77. P. Singh, R.L. Khosa, G. Mishra, Niger. J. Exp. Clin. Biosci. 1, 33-38 (2013)
78. G.M. Ebaid, L.A. Faine, Y.S. Diniz, H.G. Rodrigues, C.M. Galhardi, B.O. Ribas, A.A. Fernandes, E.L. Novelli, Food Chem. Toxicol. 44, 293-299 (2006)

79. R.M. Sarfraz, H. Khan, S. Maheen, S. Afzal, M.R. Akram, A. Mahmood, K. Afzal, M.A. Abrar, M.A. Akram, M. Andaleeb, I. Haider, K. Abbas, T. Yasmeeni, Acta Pol. Pharm. 74, 739-746 (2017)

80. J.M.A. Hannan, L. Ali, J. Khaleque, M. Akhter, P.R. Flatt, Y.H.A. Abdel-Wahab, Br. J. Nutr. 96, 131-137 (2006)

81. A. Sinha, A.K. Meena, P. Panda, B. Srivastava, M.D. Gupta, M.M. Padhi, Asian J. Res. Chem. 5, 1303-1308 (2012)

82. M. Naseri, S.Z. Khalaj, B. Ghavami, M. Kamalinezhad, G.A. Naderi, S. Faghihzadeh, J. Med. Plants 9, 57-66 (2010)

83. A. Arvindekar, T. More, P.V. Payghan, K. Laddha, N. Ghoshal, A. Arvindekar, Food Funct. 6, 2693-2700 (2015)

84. S.L. Shyaula, Nepal J. Sci. Technol. 12, 171-178 (2012)

85. A.T. Rah, S. Hemalatha, C. Elachezhiyan, Int. J. Adv. Res. Biol. Sci. 3, 27-34 (2016)

86. A. Badhani, S. Rawat, I.D. Bhatt, R.S. Rawal, J. Food Biochem. 39, 663-672 (2015)

87. U.S. Sharma, A. Kumar, J. Diabetol. 2, 4 (2011)

88. A. Verma, B. Kumar, P. Alam, V. Singh, S.K. Gupta, Int. J. Pharm. Sci. Res. 7, 2720-2731 (2016)

89. R. Baskar, L.M. Bhakshu, G. Vijaya Bharathi, S. Sreenivasa Reddy, R. Karuna, G. Kesava Reddy, D. Saralakumari, Pharm. Biol. 44, 475-479 (2006)

90. L. Brijwal, A. Pandey, S. Tamta, J. Med. Plants Res. 7, 366-370 (2013)

91. F. Alam, Q.N. Saqib, M. Ashraf, BMC Complement. Altern. Med. 18, 68 (2018)

92. M. Ahmad, M.A. Butt, G. Zhang, S. Sultana, A. Tariq, M. Zafar, Biomed. Pharmacother. 97, 708-721 (2018)

93. M. Islam, I. Azhar, K. Usmanghani, M. Aslam, A. Ahmad, Shahbuddin. Pak. J. Pharm. Sci. 15, 15-33 (2002)

94. J. Zhang, H. Ji, S. Sun, D. Mao, H. Liu, Y. Guo, J. Am. Soc. Mass Spectrom. 18, 1774-1782 (2007)

95. M.I. Kazeem, S.M. Ogungbe, G.M. Saibu, O.M. Aboyade, Bangladesh J. Pharmacol. 9, 140-145 (2014)

96. O.M. Singh, T.P. Singh, J. Sci. Ind. Res. 69, 732-740 (2010)

97. K. Poongothai, P. Ponmurugan, K.S.Z. Ahmed, B.S. Kumar, S.A. Sheriff, Asian Pac. J. Trop. Med. 4, 778-785 (2011)

98. R. Gupta, A.K. Sharma, M.C. Sharma, M.P. Dobhal, R.S. Gupta, Nat. Prod. Res. 26, 1125-1129 (2012)

99. D.M. Kar, L. Maharana, S. Pattnaik, G.K. Dash, J. Ethnopharmacol. 108, 251-256 (2006)

100. L.H.D. Jenniskens, E.L.M. van Rozendaal, T.A. van Beek, P.H.G. Wiegerinck, H.W. Scheeren, J. Nat. Prod. 59, 117-123 (1996)

101. M.R. Bhandari, N. Jong-Anurakkun, J. Kawabata, Antidiabetic potential of Nepalese herbal and food plants, in Functional Foods for Chronic Diseases, ed. by D.M. Martirosyan (D\&A, Inc., Dallas, 2008), pp. 123-132

102. B.C. Joshi, M. Mukhija, A.N. Kalia, Int. J. Green Pharm. 8, 201-209 (2014)

103. S.A. Dar, F.A. Ganai, A.R. Yousuf, M.U.H. Balkhi, T.M. Bhat, P. Sharma, Pharm. Biol. 51, 170-180 (2013)

104. M. Tanaka, E. Misawa, Y. Ito, N. Habara, K. Nomaguchi, M. Yamada, T. Toida, H. Hayasawa, M. Takase, M. Inagaki, R. Higuchi, Biol. Pharm. Bull. 29, 1418-1422 (2006)

105. A. Noor, S. Gunasekaran, M.A. Vijayalakshmi, Pharmacogn. Res. 9, 99-104 (2017)

106. K. Ashraf, S. Sultan, Int. J. Green Pharm. 11, S685 (2017)

107. P.C. Lekshmi, R. Arimboor, P.S. Indulekha, A. Nirmala Menon, Int. J. Food Sci. Nutr. 63, 832-834 (2012)

108. S.F. Nabavi, R. Thiagarajan, L. Rastrelli, M. Daglia, E. SobarzoSánchez, H. Alinezhad, S.M. Nabavi, Curr. Top. Med. Chem. 15, 2445-2455 (2015) 
109. R. Lobo, K.S. Prabhu, A. Shirwaikar, A. Shirwaikar, J. Pharm. Pharmacol. 61, 13-21 (2009)

110. M. Rahmatullah, M.N.K. Azam, S. Pramanik, S.R. Sania, R. Jahan, Int. J. Pharm. Technol. Res. 4, 125-129 (2012)

111. S. Rawat, A.K. Jugran, I.D. Bhatt, R.S. Rawal, J. Pharm. Pharmacol. 70, 687-712 (2018)

112. P.P. Reddy, A.K. Tiwari, R.R. Rao, K. Madhusudhana, V.R.S. Rao, A.Z. Ali, S.K. Babu, J.M. Rao, Bioorg. Med. Chem. Lett. 19, 2562-2565 (2009)

113. H. Kaur, Richa. Int. J. Pharmacogn. Phytochem. Res. 9, 853-857 (2017)

114. R.B. Semwal, D.K. Semwal, S. Combrinck, A.M. Viljoen, Phytochemistry 117, 554-568 (2015)

115. S.P. Akhani, S.L. Vishwakarma, R.K. Goyal, J. Pharm. Pharmacol. 56, 101-105 (2004)

116. The Ayurvedic Pharmacopoeia of India. Part I, vol I (Department of AYUSH, Ministry of Health and Family Welfare, Government of India, 2008), pp. 27-28

117. M.A. Ajabnoor, J. Ethnopharmacol. 28, 215-220 (1990)

118. B.S. Ko, S.B. Choi, S.K. Park, J.S. Jang, Y.E. Kim, S. Park, Biol. Pharm. Bull. 28, 1431-1437 (2005)

119. W. Chang, M. Zhang, J. Li, Z. Meng, S. Wei, H. Du, L. Chen, G.M. Hatch, Metabolism 62, 1159-1167 (2013)

120. Y. Hu, G.E. Davies, Fitoterapia 81, 358-366 (2010)

121. K. Kumari, K.T. Augusti, Indian J. Exp. Biol. 40, 1005-1009 (2002)

122. M. Kobori, S. Masumoto, Y. Akimoto, Y. Takahashi, Mol. Nutr. Food Res. 53, 859-868 (2009)

123. K. Meghana, G. Sanjeev, B. Ramesh, Eur. J. Pharmacol. 577, 183-191 (2007)

124. M. Chanpoo, H. Petchpiboonthai, B. Panyarachun, V. Anupunpisit, J. Med. Assoc. Thail. 93, S152-S159 (2010)

125. S. Chuengsamarn, S. Rattanamongkolgul, R. Luechapudiporn, C. Phisalaphong, S. Jirawatnotai, Diabetes Care 35, 2121-2127 (2012)

126. A.N. Balamurugan, L. Akhov, G. Selvaraj, Pancreas 38, 454-460 (2009)

127. A. Al-Romaiyan, B. Liu, H. Asare-Anane, C.R. Maity, S.K. Chatterjee, N. Koley, T. Biswas, A.K. Chatterji, G.C. Huang, S.A.
Amiel, S.J. Persaud, P.M. Jones, Phytother. Res. 24, 1370-1376 (2010)

128. R.M. Hafizur, N. Fatima, S. Shaukat, J. Cytol. Histol. 6, 1-4 (2015)

129. K. Shimizu, A. Iino, J. Nakajima, K. Tanaka, S. Nakajyo, N. Urakawa, M. Atsuchi, T. Wada, C. Yamashita, J. Vet. Med. Sci. 59, 245-251 (1997)

130. S. Cai, W. Sun, Y. Fan, X. Guo, G. Xu, T. Xu, Y. Hou, B. Zhao, X. Feng, T. Liu, Pharm. Biol. 54, 2685-2691 (2016)

131. P. Sudha, S.S. Zinjarde, S.Y. Bhargava, A.R. Kumar, BMC Complement. Altern. Med. 20, 11-15 (2011)

132. A.A.A. Salama, B.M.M. Ibrahim, N.A. Yassin, S.S. Mahmoud, A.A.G. El-Din, N.A. Shaffie, Der Pharma Chem. 9, 46-52 (2017)

133. M.F. Khan, A.K. Rawat, S. Khatoon, M.K. Hussaind, A. Mishra, D.S. Negi, Integr. Med. Res. 7, 176-183 (2018)

134. P. Gupta, U. Sharma, P.K. Gupta, R. Maurya, Chron. Young Sci. 3, 199-203 (2012)

135. K.S. Babu, A.K. Tiwari, P.V. Srinivas, A.Z. Ali, B.C. Raju, M. Rao, Bioorg. Med. Chem. Lett. 14, 3841-3845 (2004)

136. U. Devani, N. Pandita, Y. Kachwala, Asian J. Plant Sci. Res. 3, 6-14 (2013)

137. A. Mowla, M. Alauddin, M.A. Rahman, K. Ahmed, Afr. J. Tradit. Complement. Altern. Med. 6, 255-261 (2009)

138. The IUCN Red List of Threatened Species. Version 2018-1. http://www.iucnredlist.org. Accessed 5 July 2018

139. N. Srivastava, V. Sharma, B. Kamal, V.S. Jadon, Int. J. Green Pharm. 4, 220-228 (2010)

140. D. Pyakurel, I. Bhattarai Sharma, C. Smith-Hall, J. Ethnopharmacol. 224, 323-334 (2018)

141. G. Kafle, I. Bhattarai Sharma, M. Siwakoti, A.K. Shrestha, Evid. Based Complement. Altern. Med. 2018, 6024263 (2018)

142. A. Giorgi, A. Bassoli, G. Borgonovo, S. Panseri, A. Manzo, D. Pentimalli, A. Schiano Moriello, L. De Petrocellis, Phytomedicine 32, 80-87 (2017)

143. Z.A. Malik, J.A. Bhat, R. Ballabha, R.W. Bussmann, A.B. Bhatt, J. Ethnopharmacol. 172, 133-144 (2015) 